\title{
Wet and dry deposition of atmospheric nitrogen at ten sites in Northern China
}

\author{
Y. P. Pan, Y. S. Wang, G. Q. Tang, and D. Wu \\ State Key Laboratory of Atmospheric Boundary Layer Physics and Atmospheric Chemistry (LAPC), \\ Institute of Atmospheric Physics, Chinese Academy of Sciences, Beijing 100029, China
}

Correspondence to: Y. S. Wang (wys@dq.cern.ac.cn)

Received: 9 October 2011 - Published in Atmos. Chem. Phys. Discuss.: 10 January 2012

Revised: 15 May 2012 - Accepted: 21 June 2012 - Published: 25 July 2012

\begin{abstract}
Emissions of reactive nitrogen (N) species can affect surrounding ecosystems via atmospheric deposition. However, few long-term and multi-site measurements have focused on both the wet and the dry deposition of individual $\mathrm{N}$ species in large areas of Northern China. Thus, the magnitude of atmospheric deposition of various $\mathrm{N}$ species in Northern China remains uncertain. In this study, the wet and dry atmospheric deposition of different $\mathrm{N}$ species was investigated during a three-year observation campaign at ten selected sites in Northern China. The results indicate that $\mathrm{N}$ deposition levels in Northern China were high with a ten-site, threeyear average of $60.6 \mathrm{~kg} \mathrm{Nha}^{-1} \mathrm{yr}^{-1}$. The deposition levels showed spatial and temporal variation in the range of $28.5-$ $100.4 \mathrm{~kg} \mathrm{Nha}^{-1} \mathrm{yr}^{-1}$. Of the annual total deposition, $40 \%$ was deposited via precipitation, and the remaining $60 \%$ was comprised of dry-deposited forms. Compared with gaseous $\mathrm{N}$ species, particulate $\mathrm{N}$ species were not the major contributor of dry-deposited $\mathrm{N}$; they contributed approximately $10 \%$ to the total flux. On an annual basis, oxidized species accounted for $21 \%$ of total $\mathrm{N}$ deposition, thereby implying that other forms of gaseous $\mathrm{N}$, such as $\mathrm{NH}_{3}$, comprised a dominant portion of the total flux. The contribution of $\mathrm{NO}_{3}^{-}$to $\mathrm{N}$ deposition was enhanced in certain urban and industrial areas, possibly due to the fossil fuse combustion. As expected, the total $\mathrm{N}$ deposition in Northern China was significantly larger than the values reported by national scale monitoring networks in Europe, North America and East Asia because of high rates of wet deposition and gaseous $\mathrm{NH}_{3}$ dry deposition. Taken together, these findings show that $\mathrm{NH}_{3}$ emissions should be abated to mitigate high $\mathrm{N}$ deposition and associated potential impacts on ecosystems in Northern China. The present results improve our understanding of spatio-temporal
\end{abstract}

variations of magnitudes, pathways and species of deposited $\mathrm{N}$ in the target areas, and are important not only to inform conservation and regulatory bodies but also to initiate further detailed studies. Uncertainties among current observations underscore the need to quantify the impact of vegetation on dry deposition and to refine the simulation of dry deposition velocity.

\section{Introduction}

During the 20th century, humans began to significantly affect the global cycle of nitrogen $(\mathrm{N})$ by fixing $\mathrm{N}_{2}$, both deliberately for fertilizer production and inadvertently during fossil fuel combustion (Vitousek et al., 1997). The global rate of reactive $\mathrm{N}$ production increased from approximately $15 \mathrm{Tg} \mathrm{Nyr}^{-1}$ in 1860 to $187 \mathrm{Tg} \mathrm{Nyr}^{-1}$ in 2005 ; more than half of this recent total was deposited onto the ground (Gruber and Galloway, 2008). Compared with biologically fixed $\mathrm{N}$ produced on the continents, atmospherically deposited $\mathrm{N}$ is becoming a proportionately larger source of $\mathrm{N}$ for terrestrial and aquatic ecosystems worldwide (Galloway et al., 1995). In recent decades, high rates of atmospheric $\mathrm{N}$ deposition have been widely documented in Europe (Dise and Wright, 1995), North America (Fenn et al., 1998) and East Asia (Endo et al., 2010). Although elevated N deposition can stimulate plant growth in $\mathrm{N}$-limited regions and cause substantial $\mathrm{CO}_{2}$ uptake in terrestrial ecosystems (Townsend et al., 1996), there are concerns regarding the negative ecosystem health impacts of excess atmospheric $\mathrm{N}$ deposition, such as a loss of biodiversity, eutrophication, $\mathrm{N}$ saturation, soil acidification 
and increased susceptibility to secondary stresses (Liu et al., 2010).

Atmospheric $\mathrm{N}$ is deposited via precipitation (wet deposition) and as gases and particles (dry deposition) (Clark and Kremer, 2005). Therefore, it is important to quantify both the wet and the dry deposition of N; otherwise, an extrapolation of the total $\mathrm{N}$ deposition flux could yield highly uncertain estimates of potential ecological impacts. Wet deposition is readily estimated by analyzing $\mathrm{N}$ species in precipitation (Barile and Lapointe, 2005; Park and Lee, 2002; Xie et al., 2008; Larssen et al., 2006). However, the dry deposition of $\mathrm{N}$ is often omitted from observation-based flux studies because of the difficulties inherent in directly quantifying the ambient concentrations and deposition velocities of highly reactive $\mathrm{N}$ gases and speciated particles (Pryor et al., 1999). Because dry deposition can substantially contribute to total $\mathrm{N}$ deposition, neglecting dry deposition will result in an underestimation of the total deposition of $\mathrm{N}$ onto surfaces (Hill et al., 2005). Alternatively, inferential modeling has been used extensively as an operational tool to compensate for the absence of measured dry deposition data at regional scales (Flechard et al., 2011). With estimates of dry deposition and the use of monitoring networks in Europe (EMEP), North America (CASTNET) and East Asia (EANET), the total deposition flux of N at the national scale can be calculated.

According to the long-term trends observed by these networks, $\mathrm{N}$ deposition has leveled off or stabilized in the US and Europe since the late 1980s or early 1990s because of the implementation of stricter legislation to reduce emissions. In contrast, the concentrations of atmospheric reactive $\mathrm{N}$ in East Asia have continued to increase every year for the past three decades, mainly because of the increased emissions of $\mathrm{NO}_{\mathrm{x}}$ from combustion processes, $\mathrm{NH}_{3}$ from agricultural production and particulate $\mathrm{N}$ from human activities (Zheng et al., 2002). This increase is reflected in the recent finding that the total $\mathrm{N}$ deposition flux observed by EANET $\left(10.6 \mathrm{~kg} \mathrm{Nha}^{-1} \mathrm{yr}^{-1}\right)$ is larger than those reported by CASTNET $\left(5.3 \mathrm{~kg} \mathrm{Nha}^{-1} \mathrm{yr}^{-1}\right)$ and EMEP (8.7 $\mathrm{kg} \mathrm{N} \mathrm{ha}^{-1} \mathrm{yr}^{-1}$ ) (Endo et al., 2010), and is supported by peak estimates of $\mathrm{N}$ deposition over Central South China with maximum values of $63.5 \mathrm{~kg} \mathrm{Nha}^{-1} \mathrm{yr}^{-1}$ and an average value of $12.9 \mathrm{~kg} \mathrm{Nha}^{-1} \mathrm{yr}^{-1}$ (Lü and Tian, 2007). If current policies in China are fully implemented, the national emissions of $\mathrm{NO}_{\mathrm{x}}$ and $\mathrm{NH}_{3}$ are estimated to increase by $30 \%$ and $57 \%$, respectively, from 2005 to 2020 (Zhao, Y. et al., 2009). Furthermore, increasing emissions of reactive $\mathrm{N}$ species are expected to cause increased levels of atmospheric $\mathrm{N}$ deposition across most of China, and $\mathrm{N}$ deposition is expected to increase by more than $40 \%$ in certain provinces of Central South and Eastern China (Zhao, Y. et al., 2009). As one of the most rapidly developing regions in East Asia, Northern China is particularly susceptible to air pollution from increased emissions of reactive $\mathrm{N}$ species.

Despite this predicted increase in $\mathrm{N}$ deposition, the magnitude and potential impacts of atmospheric $\mathrm{N}$ deposition in Northern China remain uncertain because of a paucity of measurements and quantitative knowledge (Lü and Tian, 2007; He et al., 2007). Previous studies of $\mathrm{N}$ deposition in Northern China have considered the wet deposition and the dry deposition of N species separately (Shen et al., 2009; Zhang et al., 2008a). Furthermore, the large-scale spatial variability was not considered in previous studies, which assessed several locations in agricultural areas (Liu et al., 2006). Although $\mathrm{N}$ species in gaseous, particulate and rain phases have been measured in various locations in Northern China, relatively few studies have primarily focused on $\mathrm{N}$ deposition measurement (Meng et al., 2011; Zhang et al., 2007; Tang et al., 2005). Additionally, past work has mainly included short-term studies and has been limited to urban areas. In the absence of long-term and multi-site measurements, the effects of increasing emissions on $\mathrm{N}$ deposition in vast regions of China cannot be determined. An assessment that extends beyond a period of three years would contribute to a better understanding of regional atmospheric $\mathrm{N}$ deposition and help to identify effective strategies for mitigating $\mathrm{N}$ deposition in the future.

The objective of this study was to investigate spatiotemporal variations in the total atmospheric $\mathrm{N}$ deposition flux and thereby establish baseline information for future studies in various areas of Northern China. The atmospheric deposition of $\mathrm{N}$ species via particles, precipitation and gaseous processes was examined over a three-year sampling period at ten selected sites with varying urban geographies, energy structures and ecosystem types.

\section{Materials and methods}

\subsection{Site descriptions}

The study was conducted between December 2007 and November 2010 across Northern China, which is an area of growing concern regarding the effects of increased $\mathrm{N}$ emissions on receiving terrestrial and aquatic ecosystems. The ten sites were selected to provide regional information on $\mathrm{N}$ deposition and thereby advance our current understanding of the effects on different environments. The sites included the two mega cities of Beijing (BJ) and Tianjin (TJ), the two suburban areas of Cangzhou (CZ) and Yangfang (YF), the three industrial sites of Baoding (BD), Tanggu (TG) and Tangshan (TS), the two agricultural areas of Luancheng (LC) and Yucheng (YC) and a rural site at Xinglong (XL). The general location of each site is shown in Fig. 1. The longitudes ranged from $114.69^{\circ} \mathrm{E}$ to $118.20^{\circ} \mathrm{E}$, and the latitudes ranged from $36.85^{\circ} \mathrm{N}$ to $40.38^{\circ} \mathrm{N}$. The annual mean precipitation ranged from 404 to $610 \mathrm{~mm}$, and the air temperature from 8.8 to $13.4^{\circ} \mathrm{C}$. The measurement height and other available information on the monitoring sites, such as the main land use type, possible emissions and density of population, are listed in detail in Table 1. 

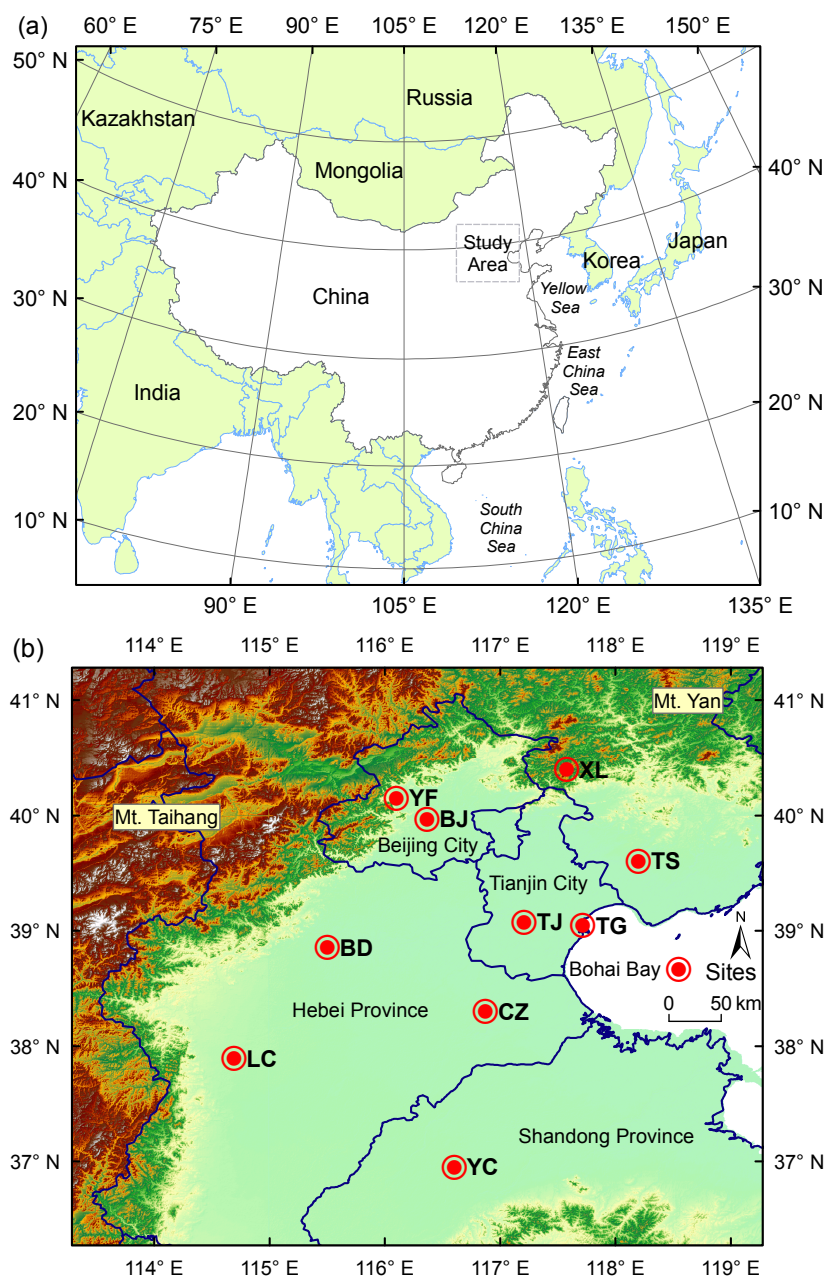

Fig. 1. Locations of the study area and the sampling sites in Northern China. Of the ten selected sites, two mega city sites are located in the Beijing (BJ, 39.96 $\mathrm{N}, 116.36^{\circ} \mathrm{E}$ ) and Tianjin (TJ, $39.08^{\circ} \mathrm{N}, 117.21^{\circ} \mathrm{E}$ ) downtown areas; two suburban sites $2 \mathrm{~km}$ southeast of Cangzhou city $\left(\mathrm{CZ}, 38.30^{\circ} \mathrm{N}, 116.87^{\circ} \mathrm{E}\right)$ and at Yangfang (YF, $40.15^{\circ} \mathrm{N}, 116.10^{\circ} \mathrm{E}$ ), which is $40 \mathrm{~km}$ northwest of Beijing city; three industrial city sites in the center of Baoding city $\left(\mathrm{BD}, 38.85^{\circ} \mathrm{N}, 115.50^{\circ} \mathrm{E}\right)$, south of Tangshan city (TS, $39.60^{\circ} \mathrm{N}$, $118.20^{\circ} \mathrm{E}$ ) and in the coastal Tanggu (TG, $39.04^{\circ} \mathrm{N}, 117.72^{\circ} \mathrm{E}$ ) area, which is $30 \mathrm{~km}$ east of Tianjin city; two agricultural sites $6 \mathrm{~km}$ southwest of Yucheng city $\left(\mathrm{YC}, 36.85^{\circ} \mathrm{N}, 116.55^{\circ} \mathrm{E}\right)$ and at Luancheng ( $\mathrm{LC}, 37.89^{\circ} \mathrm{N}, 114.69^{\circ} \mathrm{E}$ ), which is $4 \mathrm{~km}$ southeast of Shijiazhuang city; and one rural site at Xinglong (XL, $40.38^{\circ} \mathrm{N}$, $117.57^{\circ} \mathrm{E}$ ) on Mt. Yan, with an elevation of $960 \mathrm{~m}$ a.s.l.

In order to understand the geographical patterns of the observed $\mathrm{N}$ depositions, emission distributions of the precursors have to be known. Emissions of $\mathrm{NO}_{\mathrm{x}}$ and $\mathrm{NH}_{3}$ in the year 2008 have been aggregated into model grids at a resolution of $9 \times 9 \mathrm{~km}^{2}$ and are shown in Sect. 3.4.4 (Fig. 6). The $\mathrm{NH}_{3}$ emission data include human and livestock excrement, agricultural applications and sewage treatment plants, whereas the $\mathrm{NO}_{\mathrm{x}}$ data consist of vehicles, power plants and industrial and residential sources (Tang, 2010). A detailed discussion of the emission inventory is underway and will be published elsewhere in the near future.

\subsection{Wet deposition measurements}

Daily rainwater and monthly particulate dry deposition samples were collected using a custom wet-dry automatic collector (APS-2B, Xianglan Scientific Instruments Co., Ltd., Changsha, China). The wet-dry samplers were equipped with a $707 \mathrm{~cm}^{2}$ aperture and a $177 \mathrm{~cm}^{2}$ glass bucket to sample wet and particulate dry deposition, respectively. The precipitation sensor opens the collection funnel of the cover device when rainfall begins, and rainwater flows from the funnel into a 151 plastic bottle. The funnel lid closes automatically when the precipitation ceases and the rainwater has evaporated from the sensor surface. This feature of the collector is highly useful for simultaneously collecting samples of rainwater and deposited particles with minor mixing of the two. After sampling, the collection system is systematically cleaned with distilled water. Snow samples were collected using a clean plastic bucket with an inner diameter of $22 \mathrm{~cm}$ as soon as possible after the snowfall events. The top $3-5 \mathrm{~cm}$ of snow was collected and melted in a $500 \mathrm{ml}$ glass beaker at room temperature. In addition, another plastic bucket was also used to collect snow samples synchronously, which were used for measuring the water equivalent depths of snowfall. The rainwater and melted snow samples were frozen in a refrigerator at $-20^{\circ} \mathrm{C}$ at each site immediately after collection and were delivered in iceboxes to analytical laboratories in the State Key Laboratory of Atmospheric Boundary Layer Physics and Atmospheric Chemistry (LAPC, in Beijing) by routine monthly site-maintenance visits. Each sample was filtered with a syringe (Minisart SRP 25 of diameter $0.45 \mu \mathrm{m}$, Sartorius, Germany), and $15 \mathrm{ml}$ filtrates were then frozen and stored in plastic bottles until chemical analysis. Though the pre-treatment of precipitation (rainwater and snow) samples has been described in previous studies (Pan et al., 2010a), it is repeated here for the reader's convenience.

The species and amounts of inorganic $\mathrm{N}$ (IN), including $\mathrm{NH}_{4}^{+}, \mathrm{NO}_{3}^{-}$and $\mathrm{NO}_{2}^{-}$, in the precipitation samples were determined using an ion chromatography system (Model ICS90, Dionex Corporation, Sunnyvale, CA, USA) and the standard laboratory procedure of LAPC (Wang et al., 2012). The detection limit (DL) of $\mathrm{N}$ for this instrument was $5 \mu \mathrm{g} 1^{-1}$. The average concentrations of the $\mathrm{N}$ species in the field blanks were well below the DL, thereby indicating that no significant contamination of the rain samples occurred during the sampling, handling, filtration or measurement steps. The monthly wet deposition flux of IN $\left({ }_{w} \mathrm{IN}\right)$ was obtained by multiplying the volume-weighted concentrations of IN in the precipitation and the amount of precipitation measured by a standard rain gauge at each site during the corresponding period. Though unstable $\mathrm{NO}_{2}^{-}$is readily converted to $\mathrm{NO}_{3}^{-}$ and cannot be well kept prior to analysis, the concentration 
Table 1. Descriptions of the ten sampling sites in Northern China.

\begin{tabular}{|c|c|c|c|c|c|c|c|c|c|c|c|}
\hline \multirow{2}{*}{ Site } & \multirow{2}{*}{ Coordinates } & \multirow{2}{*}{ Classification } & \multicolumn{3}{|c|}{$\begin{array}{l}\text { Measurement height }(\mathrm{m}) \\
\text { and underlying surface }\end{array}$} & \multicolumn{4}{|c|}{ Meteorological parameters ${ }^{b}$} & \multirow{2}{*}{$\begin{array}{l}\text { Surrounding environment and } \\
\text { possible emission sources }{ }^{\mathrm{c}}\end{array}$} & \multirow{2}{*}{ 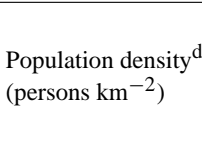 } \\
\hline & & & Rain & Gases & Surface & $\begin{array}{l}\text { Rainfall } \\
(\mathrm{mm})\end{array}$ & $\begin{array}{l}\text { Wind speed } \\
\left(\mathrm{m} \mathrm{s}^{-1}\right)\end{array}$ & $\begin{array}{l}T \\
\left({ }^{\circ} \mathrm{C}\right)\end{array}$ & $\begin{array}{l}\mathrm{RH} \\
(\%)\end{array}$ & & \\
\hline BJ & $\begin{array}{l}39.96^{\circ} \mathrm{N} \\
116.36^{\circ} \mathrm{E}\end{array}$ & Urban & 8 & 8 & Roof & 572 & 2.5 & 12.3 & 57 & $\begin{array}{l}\text { Densely occupied residences } \\
\text { and traffic roads }\end{array}$ & 5479 \\
\hline $\mathrm{TJ}$ & $\begin{array}{l}39.08^{\circ} \mathrm{N} \\
117.21^{\circ} \mathrm{E}\end{array}$ & Urban & 1.5 & 6 & Lawn & 544 & 2.5 & 12.7 & 62 & $\begin{array}{l}\text { Densely occupied residences, } \\
\text { industry and traffic roads }\end{array}$ & 24606 \\
\hline BD & $\begin{array}{l}38.85^{\circ} \mathrm{N} \\
115.50^{\circ} \mathrm{E}\end{array}$ & Industrial & 10.5 & 11 & Roof & 513 & 2.1 & 12.9 & 62 & $\begin{array}{l}\text { Densely occupied residences, } \\
\text { traffic roads and industry }\end{array}$ & 2871 \\
\hline TG & $\begin{array}{l}39.04^{\circ} \mathrm{N} \\
117.72^{\circ} \mathrm{E}\end{array}$ & Industrial & 1.5 & 2 & Lawn & 566 & 4.3 & 12.6 & 64 & Light industry and traffic roads & 865 \\
\hline TS & $\begin{array}{l}39.60^{\circ} \mathrm{N} \\
118.20^{\circ} \mathrm{E}\end{array}$ & Industrial & 13.5 & 14 & Roof & 610 & 2.4 & 11.5 & 62 & $\begin{array}{l}\text { Densely occupied residences, } \\
\text { traffic roads and industry }\end{array}$ & 2648 \\
\hline YF & $\begin{array}{l}40.15^{\circ} \mathrm{N} \\
116.10^{\circ} \mathrm{E}\end{array}$ & Suburban & 1.5 & 2 & Grass & 404 & 2.5 & 8.8 & 47 & $\begin{array}{l}\text { Occupied residences } \\
\text { and traffic roads }\end{array}$ & 470 \\
\hline $\mathrm{CZ}$ & $\begin{array}{l}38.30^{\circ} \mathrm{N} \\
116.87^{\circ} \mathrm{E}\end{array}$ & Suburban & 5.5 & 6 & Roof & 605 & 3 & 12.9 & 61 & Small villages and highways & 2314 \\
\hline LC & $\begin{array}{l}37.89^{\circ} \mathrm{N} \\
114.69^{\circ} \mathrm{E}\end{array}$ & Agricultural & 1.5 & 2 & Lawn & 517 & 1.8 & 13.4 & 62 & Small villages and cropland & 958 \\
\hline YC & $\begin{array}{l}36.85^{\circ} \mathrm{N} \\
116.55^{\circ} \mathrm{E}\end{array}$ & Agricultural & 1.5 & 1.5 & Lawn & 566 & 2.3 & 13.2 & 63 & Small villages and cropland & 521 \\
\hline $\mathrm{XL}$ & $\begin{array}{l}40.38^{\circ} \mathrm{N} \\
117.57^{\circ} \mathrm{E}\end{array}$ & Rural & 1.5 & 8 & Grass & 512 & 1.1 & 9.1 & 55 & Forest and few villages & 98 \\
\hline
\end{tabular}

a The automatic wet-dry collector (height, $1.5 \mathrm{~m}$ ) was installed on the ground if the underlying surface of the site was grass or lawn. When the underlying surface was bared soil or concrete road, it was installed on the roof of a building available at the station to avoid local emissions such as re-suspended particles. Therefore, the rainfall was collected at the height of $1.5-13.5 \mathrm{~m}$ above the ground. The passive sampler to measure the ambient concentrations of gaseous $\mathrm{N}$ species was installed at a similar height to or $0.5 \mathrm{~m}$ higher than that of the automatic wet-dry collector at most of the sites, whereas at the XL and TJ sites, the passive sampler was installed on the rooftop and the tower with a measurement height of $8 \mathrm{~m}$ and $6 \mathrm{~m}$ above the ground, respectively.

$\mathrm{b}$ There were no mean annual meteorological data for the ten monitoring sites; the surface climate parameters presented (1971-2000) were obtained from the nearest meteorological observation stations available on the China Meteorological Data Sharing Services System website (http://cdc.cma.gov.cn/).

$\mathrm{c}^{\mathrm{c}}$ The main soil type in the North China Plain is silty loam alluvial soil (FAO system) with an average bulk density of $1.5 \mathrm{~g} \mathrm{~cm}{ }^{-3}$. The dominant cropping system in the region is a winter wheat-summer maize rotation system (two crops a year). Farmers typically apply about $500 \mathrm{~kg} \mathrm{Nha}^{-1} \mathrm{yr}^{-1}$ as N fertilizer in March-April, June-August and October to achieve high yields of maize and wheat. During the observation period, the annual N fertilizer input at the $\mathrm{YC}^{\mathrm{site}}$ was ca. 500,280 and $520 \mathrm{~kg} \mathrm{~N}^{-1} \mathrm{yr}^{-1}$ in $^{-1}$

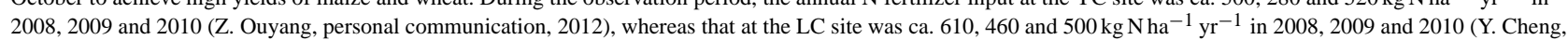
personal communication, 2012), respectively.

$\mathrm{d}$ The population density was estimated by dividing population by area of the town/district/county in which the monitoring site is located. Population data were retrieved from the fifth census of China in 2000 and can be accessed online (http://www.stats.gov.cn).

of $\mathrm{NO}_{2}^{-}$was determined here to investigate the $\mathrm{N}$ pool in precipitation and dry-deposited particles. The results showed that $\mathrm{NO}_{2}^{-}$is an insignificant fraction of the atmospheric $\mathrm{N}$ budget.

\subsection{Particulate dry deposition measurements}

Although the amount of wet deposition can be determined directly from precipitation samples, dry deposition measurements are much more challenging (Wesely and Hicks, 2000). In this study, a polyurethane foam (PUF) filter $(7.5 \mathrm{~cm}$ diameter and $1.35 \mathrm{~cm}$ thickness with a density of $\left.0.021 \mathrm{~g} \mathrm{~cm}^{-3}\right)$, used as a surrogate surface, was placed in the glass bucket $(7.5 \mathrm{~cm}$ inner diameter and $30 \mathrm{~cm}$ depth) to collect the drydeposited airborne particles for chemical analysis (Pan et al., 2010b). During a rain event, the glass bucket for collecting the dry deposition was covered with a lid. After the precipitation ceased, the lid was lifted and rotated to cover the aperture that collected the rainwater; this simultaneously opened the glass bucket to collect dry-deposited particles.

After collection, the PUF filters were sealed in aluminum foil and frozen in a refrigerator at each site until delivery in iceboxes to LAPC by routine monthly site-maintenance visits. In analytical laboratories, the PUF filters were conditioned in a dry box at $40 \%$ relative humidity and $25^{\circ} \mathrm{C}$ for $24 \mathrm{~h}$ to measure the pre- and post-sampling weights and to determine the mass collected on the filters. The monthly dry deposition flux of particulate matter was calculated by dividing the mass by the surrogate surface area during the sampling period. To determine the content of extractable IN in the deposited particles, the PUF filters were cut into ten to twenty equal portions. The water-soluble species were then extracted from three duplicate portions by adding $50 \mathrm{ml}$ of ultrapure water, ultrasonicating for 30-60 min and filtering through a $0.45 \mu \mathrm{m}$ membrane. Ion chromatography was either performed immediately or the sample was stored in a refrigerator at $4{ }^{\circ} \mathrm{C}$ until the analysis. The results from the triplicate samples were averaged after subtraction of the blank and were used to estimate the particulate dry deposition flux of IN ( $\mathrm{p} I \mathrm{~N})$. The field blanks did not significantly influence the observed data. 


\subsection{Gaseous dry deposition measurements}

The inferential technique, which combines measured concentrations and modeled dry deposition velocities $\left(V_{\mathrm{d}}\right)$, was used to estimate the gaseous dry deposition flux of $\mathrm{N}$ species (Schwede et al., 2011). The ambient $\mathrm{NO}_{2}, \mathrm{NO}_{\mathrm{x}}$ and $\mathrm{NH}_{3}$ concentrations were estimated according to the $\mathrm{NO}_{2}^{-}$and $\mathrm{NH}_{4}^{+}$levels measured in the extracts of diffusive samplers (Analyst, CNR-Institute of Atmospheric Pollution, Roma, Italy) by considering the local temperature and humidity conditions of the site, in accordance with the Analyst practical guide (Perrino and Catrambone, 2004; Costabile et al., 2006). Because the $\mathrm{NO}_{2}$ and $\mathrm{NO}_{\mathrm{x}}$ samplers were exposed simultaneously over a period of a month, monthly concentration of NO could be calculated as the difference between the two values. Previous comparisons between passive samplers and in situ continuous active analyzers for these reactive $\mathrm{N}$ species indicated that the Analyst passive sampler is reliable for such a study (Wu et al., 2010).

The hourly $V_{\mathrm{d}}$ of gaseous $\mathrm{NO}, \mathrm{NO}_{2}$ and $\mathrm{NH}_{3}$ were simulated using the Models-3/Community Multiscale Air Quality (CMAQ v4.6) system (Byun and Ching, 1999). This model has proven to be suitable for regional and urban atmospheric pollution and deposition simulations in China (Zhao, Y. et al., 2009). The driving meteorological inputs were provided by the fifth-generation NCAR/Penn State Mesoscale Model (MM5 v3.7). The monthly-average $V_{\mathrm{d}}$ of $\mathrm{NO}_{2}, \mathrm{NO}$ and $\mathrm{NH}_{3}$ were multiplied with their ambient concentrations measured by passive samplers during the corresponding period to obtain the gaseous dry deposition flux of IN $\left({ }_{\mathrm{g}} \mathrm{IN}\right)$.

The default $V_{\mathrm{d}}$ implemented by CMAQ v4.6 in its second dry deposition scheme (M3Dry) is parameterized following the well-known resistance approach (Wesely, 1989). Three resistances are considered in this theory: aerodynamic resistance $\left(R_{\mathrm{a}}\right)$, quasi-laminar resistance $\left(R_{\mathrm{b}}\right)$, and surface or canopy resistance $\left(R_{\mathrm{c}}\right)$, among which the $R_{\mathrm{c}}$ is the most difficult one to simulate (Zhang et al., 2008b). The $V_{\mathrm{d}}$ is expressed as

$V_{\mathrm{d}}=\left(R_{\mathrm{a}}+R_{\mathrm{b}}+R_{\mathrm{c}}\right)^{-1}$.

$V_{\mathrm{d}}$ here was taken from a height of $38 \mathrm{~m}$ above ground, which is the center of the lowest layer in the CMAQ model. Although $V_{\mathrm{d}}$ is calculated not according to the measurement height at each site, it results in insignificant errors in flux estimates, because the differences of $V_{\mathrm{d}}$ between 10 and $50 \mathrm{~m}$ were estimated in previous reports to be only a few percent under neutral and unstable atmospheric conditions (Zhang et al., 2005). On the other hand, during the night when the conditions are stable, $V_{\mathrm{d}}$ was much lower due to the limited vertical dispersion of pollutants (Zhou et al., 2010).

Different from most gases that are consistently deposited, the surface-atmosphere exchange of $\mathrm{NH}_{3}$ is bi-directional, but in CMAQ v4.6 it is treated as dry deposition only (Byun and Ching, 1999). Bi-directional exchange of $\mathrm{NH}_{3}$ was developed in the latest version of CMAQ v5.0, but cannot be applied in the present study due to the lack of input parameters. Since the principle of bi-directional $\mathrm{NH}_{3}$ exchange was not involved in the present study, the flux calculated here represents a rather non-conservative $\mathrm{N}$ deposition estimate (upper boundary). The overestimation may be significant over managed agricultural ecosystems, because the canopy compensation point is generally larger over agricultural crops and fertilized vegetation (Zhang et al., 2010; Marner and Harrison, 2004). Therefore, the effects of the stomatal compensation point on $\mathrm{NH}_{3}$ deposition in agricultural sites due to the counterbalance between deposition and emission are discussed in Sect. 3.5.4.

\subsection{Statistics}

A one-way analysis of variance (ANOVA) and nonparametric tests were conducted to examine the significance of differences in the annual wet and dry deposition flux of $\mathrm{N}$ species for all ten sites over the three years of the study. A paired T-test was not applied in this study, because the atmospheric deposition flux of $\mathrm{N}$ species was not always normally distributed, neither among the ten sites nor in different seasons. A linear regression analysis was used to investigate relationships between precipitation and the wet deposition of IN or relationships between measured species (e.g., $\mathrm{SO}_{4}^{2-}$ vs. $\mathrm{NO}_{3}^{-}$). All statistical analyses were performed using the software Origin 8.0 (Origin Lab Corporation, Northampton, MA, USA) and SPSS 11.5 (SPSS Inc., Chicago, IL, USA).

\section{Results and discussion}

\subsection{Wet deposition flux of $\mathrm{N}$ species}

\subsubsection{Spatial variations of ${ }_{w}$ IN}

The mean annual ${ }_{\mathrm{w}} \mathrm{IN}$ at the ten sites during the period from 2008 to 2010 ranged from 16.3 to $28.2 \mathrm{~kg} \mathrm{~N} \mathrm{ha}^{-1} \mathrm{yr}^{-1}$, with $63 \%$ to $78 \%$ in the reduced $\mathrm{NH}_{4}^{+}$form (Fig. 2a). The contribution of $\mathrm{NO}_{3}^{-}$to the ${ }_{\mathrm{w}} \mathrm{IN}(21-36 \%)$ was less than that of $\mathrm{NH}_{4}^{+}$, whereas $\mathrm{NO}_{2}^{-}$played a minor or insignificant role. The wet deposition flux of $\mathrm{NH}_{4}^{+}\left({ }_{\mathrm{w}} \mathrm{NH}_{4}^{+}\right)$was, on average, 2.7-times greater than that of $\mathrm{NO}_{3}^{-}\left({ }_{\mathrm{w}} \mathrm{NO}_{3}^{-}\right)$. This difference was more pronounced in the agricultural sites ( $\mathrm{LC}$ and YC), thereby indicating that ${ }_{\mathrm{w}} \mathrm{NH}_{4}^{+}$had a greater contribution to ${ }_{w} \mathrm{IN}$ in agricultural areas than in urban and industrial areas. The estimated ${ }_{\mathrm{w}} \mathrm{IN}$ varied among the sites; the highest values occurred at the TG site $\left(28.2 \mathrm{~kg} \mathrm{~N} \mathrm{ha}^{-1} \mathrm{yr}^{-1}\right)$ followed by the $\mathrm{BJ}$ and $\mathrm{YC}$ sites (27.9 and $24.8 \mathrm{~kg} \mathrm{~N} \mathrm{ha}^{-1} \mathrm{yr}^{-1}$ ). The ${ }_{w}$ IN results were similar for the BD, CZ, LC, TS, YF and TJ sites, with values of 23.1, 22.6, 22.2, 21.6, 20.7 and $18.1 \mathrm{~kg} \mathrm{Nha}^{-1} \mathrm{yr}^{-1}$, respectively. As expected, the lowest flux was observed at the rural XL site, with a three-year mean value of $16.3 \mathrm{~kg} \mathrm{Nha}^{-1} \mathrm{yr}^{-1}, 10-42 \%$ lower than that of the other sites. However, the differences were not significant 

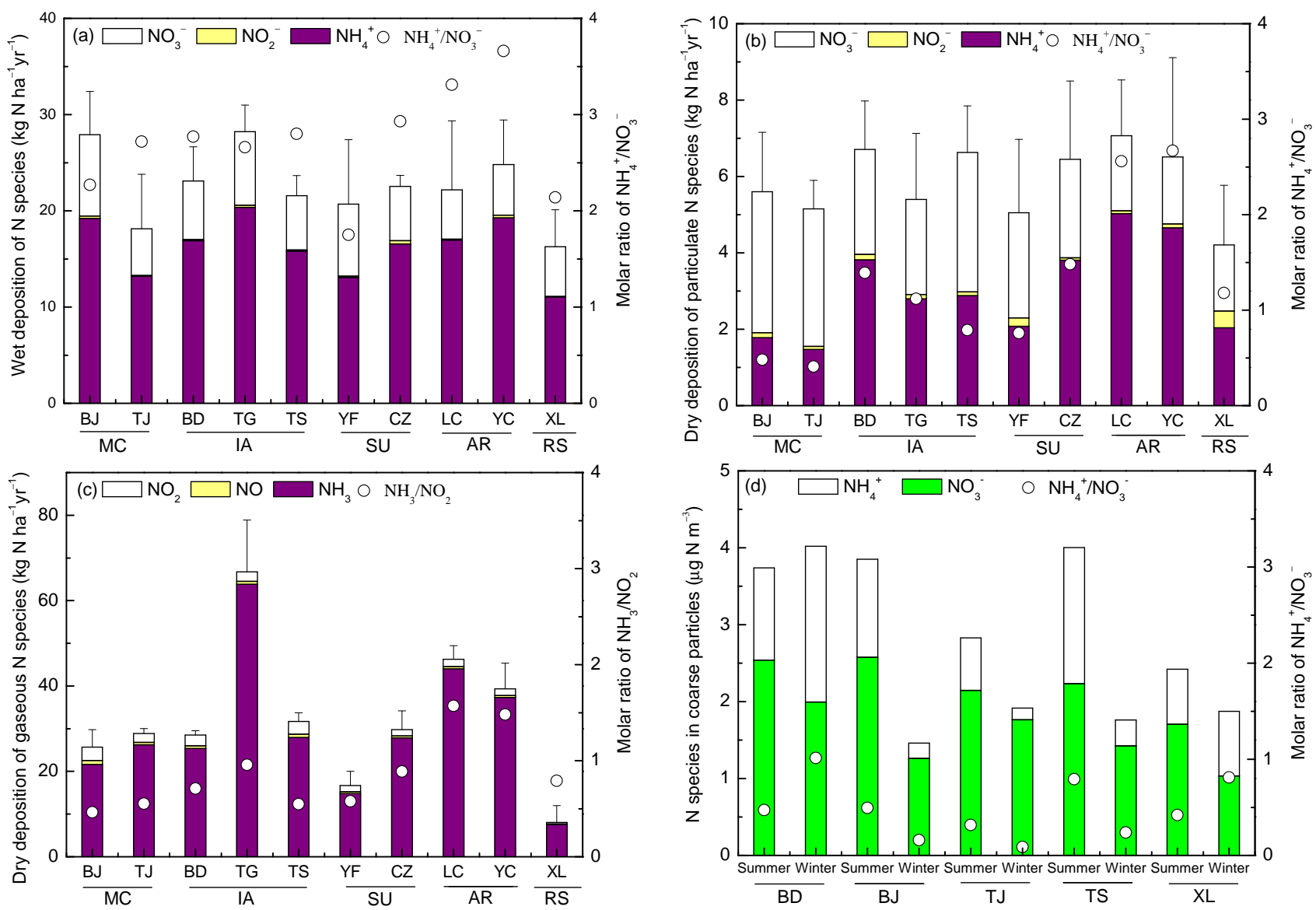

Fig. 2. Atmospheric deposition flux of nitrogen species at the ten selected sites in Northern China. The data shown are means of three-year observations, with the error bars denoting standard deviation. MC, IA, SU, AR and RS denote urban, industrial, suburban, agricultural and rural sites, respectively. The definition of the site codes is found in the caption of Fig. 1. The molar ratios of $\mathrm{NH}_{4}^{+}$to $\mathrm{NO}_{3}^{-}$in precipitation (a) and dry-deposited particles (b) were calculated using flux data, whereas the molar ratio of gaseous $\mathrm{NH}_{3}$ to $\mathrm{NO}_{2}$ was calculated using concentration data $(\mathbf{c})$. The concentrations of $\mathrm{NH}_{4}^{+}$and $\mathrm{NO}_{3}^{-}$in coarse particles with a diameter larger than $2.1 \mu \mathrm{m}(\mathbf{d})$ are derived from our previous size-resolved compositional analysis performed for particles between 0.1 and $100 \mu \mathrm{m}$ diameter over bi-weekly intervals during the winter (from December 2009 to February 2010) and summer (from June to August 2010) at the five sites simultaneously (Sun, 2011). The daily aerosol samples were collected on Teflon filters with an $81 \mathrm{~mm}$ diameter using a nine-stage cascade impactor (Anderson Series 20-800, USA) at a flow rate of $28.31 \mathrm{~min}^{-1}$. Therefore, in total, during the period of study, 12 sampling campaigns were carried out at each site. The pre-treatment and analysis of the samples were similar to the PUF filters described in Sect. 2.3.

( $p>0.05$ ) between the sites or the different years, thus indicating the absence of a geographic trend in the spatial distribution of wet deposition.

\subsubsection{Seasonal variations of ${ }_{w} I N$}

The mean monthly wet deposition flux of $\mathrm{N}$ species monitored for the three years ranged from 0 to $12.4 \mathrm{~kg} \mathrm{Nha}^{-1}$ month $^{-1}$ for $\mathrm{NH}_{4}^{+}$and from 0 to $3.9 \mathrm{~kg} \mathrm{Nha}^{-1}$ month $^{-1}$ for $\mathrm{NO}_{3}^{-}$(Fig. 3a, b). The seasonal variations of these two $\mathrm{N}$ species were similar at each site: they were higher during the summer than in the spring, autumn or winter, which corresponded with the seasonal distribution of precipitation levels in Northern China. For example, the total ${ }_{\mathrm{w}} \mathrm{NH}_{4}^{+}$and ${ }_{\mathrm{w}} \mathrm{NO}_{3}^{-}$throughout the summer
(June to August) were, on average, 10.7 and $3.5 \mathrm{~kg} \mathrm{~N} \mathrm{ha}^{-1}$, respectively, for the ten sites during the three-year period; ${ }_{w} \mathrm{NH}_{4}^{+}$and ${ }_{\mathrm{w}} \mathrm{NO}_{3}^{-}$accounted for $66 \%$ and $57 \%$ of the annual ${ }_{w} I N$, respectively. Correspondingly, the study area received $364 \mathrm{~mm}$ of rain during the summer, accounting for $66 \%$ of the total annual precipitation. On the other hand, the minimum ${ }_{\mathrm{w}} \mathrm{IN}$ level that occurred in the winter season was attributable to a decrease in precipitation. In general, a positive relationship between the monthly deposition of $\mathrm{N}$ species $\left(\mathrm{NH}_{4}^{+}\right.$and $\left.\mathrm{NO}_{3}^{-}\right)$and precipitation was observed at each site $\left(0.57<r^{2}<0.88, p<0.001\right)$, thereby indicating that the rainfall amount was an important controlling influence on the seasonal trends of $\mathrm{N}$ wet deposition.

The above-mentioned positive relationship is similar to that observed between dissolved organic carbon and the 

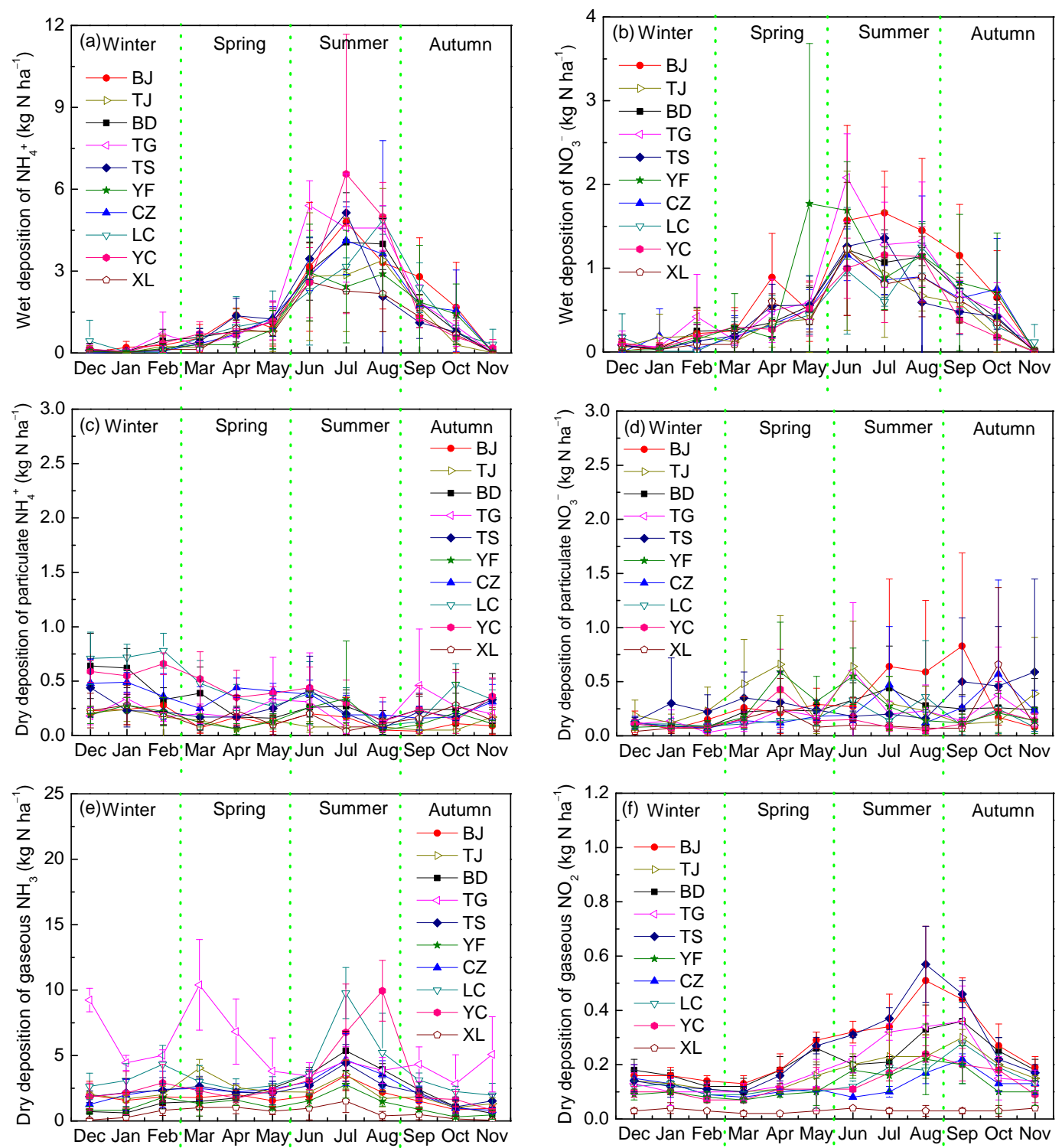

Fig. 3. Seasonal variations of the atmospheric deposition flux of nitrogen species at the ten selected sites in Northern China. The data shown are the monthly mean \pm standard deviations of three-year observations (from December 2007 to November 2010). The definition of the site codes is found in the caption of Fig. 1.

amount of precipitation in the target areas (Pan et al., 2010a). Previous studies have also reported consistent precipitation effects on the wet deposition of $\mathrm{N}$ and other soluble species (Zhao, X. et al., 2009; Zhang et al., 2008a; Guo et al., 2008), thus suggesting that the amount of rainfall influences the seasonal trends of wet deposition at a given site. However, the wet deposition of $\mathrm{N}$ species in June through September fluctuated dramatically between the sites (Fig. 3a, b), and differences between the precipitation and deposition trends were observed (Fig. 4a). These monthly fluctuations could be partially explained by the variable amounts of precipitation. However, differences in the precursor atmospheric concentrations of $\mathrm{N}$ species are also contributing factors.

\subsubsection{Effects of the precipitation amount on annual ${ }_{w}$ IN}

Factors influencing the regional variations of annual wet deposition were investigated on the basis of the scavenging ratios following previous studies (Sakata et al., 2006). The concept of the scavenging ratio is based on the simplified assumption that the concentration of a component in precipitation $\left(C_{\mathrm{p}}\right)$ is related to the concentration of the respective compound in the air $\left(C_{\mathrm{a}}\right)$. Thus, the scavenging ratio can be calculated on a mass basis

$W=C_{\mathrm{p}} / C_{\mathrm{a}}$. 
When the precipitation amount is expressed as $P$, the wet deposition flux of the constituents $(F)$ depends on $W, C_{\mathrm{a}}$ and $P$ by

$F=W C_{\mathrm{a}} P$.

Therefore, if the scavenging ratio and atmospheric concentrations are constant in the region, the wet deposition flux increases in proportion to the precipitation amount. However, for the sites with higher concentrations of pollutants, the wet deposition flux was greater than expected from the amount of precipitation based on the above premise (i.e., $W C_{\mathrm{a}}=$ constant). This allows us to evaluate the degree influenced by anthropogenic emissions at each site, using the relationship between the wet deposition of $\mathrm{N}$ species and the precipitation amount.

The statistical analysis of data from the three-year period revealed a positive relationship between the annual ${ }_{\mathrm{w}} \mathrm{IN}$, particularly between the ${ }_{\mathrm{w}} \mathrm{NH}_{4}^{+}$and the corresponding precipitation amounts $(p<0.001)$ (Fig. 4b). However, only $35 \%$ and $44 \%$ of the variance of the ${ }_{\mathrm{w}} \mathrm{IN}\left(r^{2}=0.35\right)$ and ${ }_{\mathrm{w}} \mathrm{NH}_{4}^{+}$ $\left(r^{2}=0.44\right)$, respectively, were explained by the amount of precipitation. The results suggest marked differences in the scavenging ratio and the atmospheric concentrations of $\mathrm{N}$ compounds across Northern China. Specifically, the ${ }_{w} \mathrm{NH}_{4}^{+}$ values at the BJ, LC and TS sites in certain years tended to be much higher than those expected from the precipitation amount, thereby indicating a large contribution of anthropogenic emissions. However, the relatively low ${ }_{\mathrm{w}} \mathrm{NH}_{4}^{+}$values at the XL site compared with those expected from the precipitation amount may be due to the lower number of anthropogenic sources in the rural areas. In contrast to the trends of ${ }_{\mathrm{w}} \mathrm{IN}$ and ${ }_{\mathrm{w}} \mathrm{NH}_{4}^{+}$, the annual ${ }_{\mathrm{w}} \mathrm{NO}_{3}^{-}$values were not significantly correlated with the precipitation amount (Fig. 4b), likely because the annual ${ }_{\mathrm{w}} \mathrm{NO}_{3}^{-}$values were strongly dependent on local anthropogenic sources.

\subsubsection{Source information of $\mathbf{N}$ species in precipitation}

To obtain additional source information on the wet deposition at the local scale, the molar ratio of $\mathrm{NH}_{4}^{+} / \mathrm{NO}_{3}^{-}$was calculated and is presented in Fig. 2a. The molar ratio of $\mathrm{NH}_{4}^{+} / \mathrm{NO}_{3}^{-}$varied between 1.8 (YF) and 3.3 (LC), and the average was 2.7. The results indicate that $\mathrm{NH}_{3}$ from agriculture and human and animal excrement remains the major contributor to wet $\mathrm{N}$ deposition in the target areas, compared with the $\mathrm{NO}_{3}^{-}$from fossil fuel combustion in industry and transportation (Fahey et al., 1999). This fact was more pronounced at the agricultural sites, YC and LC, than at certain industrial and urban sites such as BD, TJ and TS. However, for the wet $\mathrm{N}$ deposition, the contribution from $\mathrm{NO}_{3}^{-}$was relatively more important at the $\mathrm{BJ}, \mathrm{XL}$ and $\mathrm{YF}$ sites, considering that the ratio of $\mathrm{NH}_{4}^{+} / \mathrm{NO}_{3}^{-}$at these sites was much lower than the values at the other sites. Of note is that ${ }_{\mathrm{w}} \mathrm{NO}_{3}^{-}$in certain months at the mega city BJ site (April, June-September)
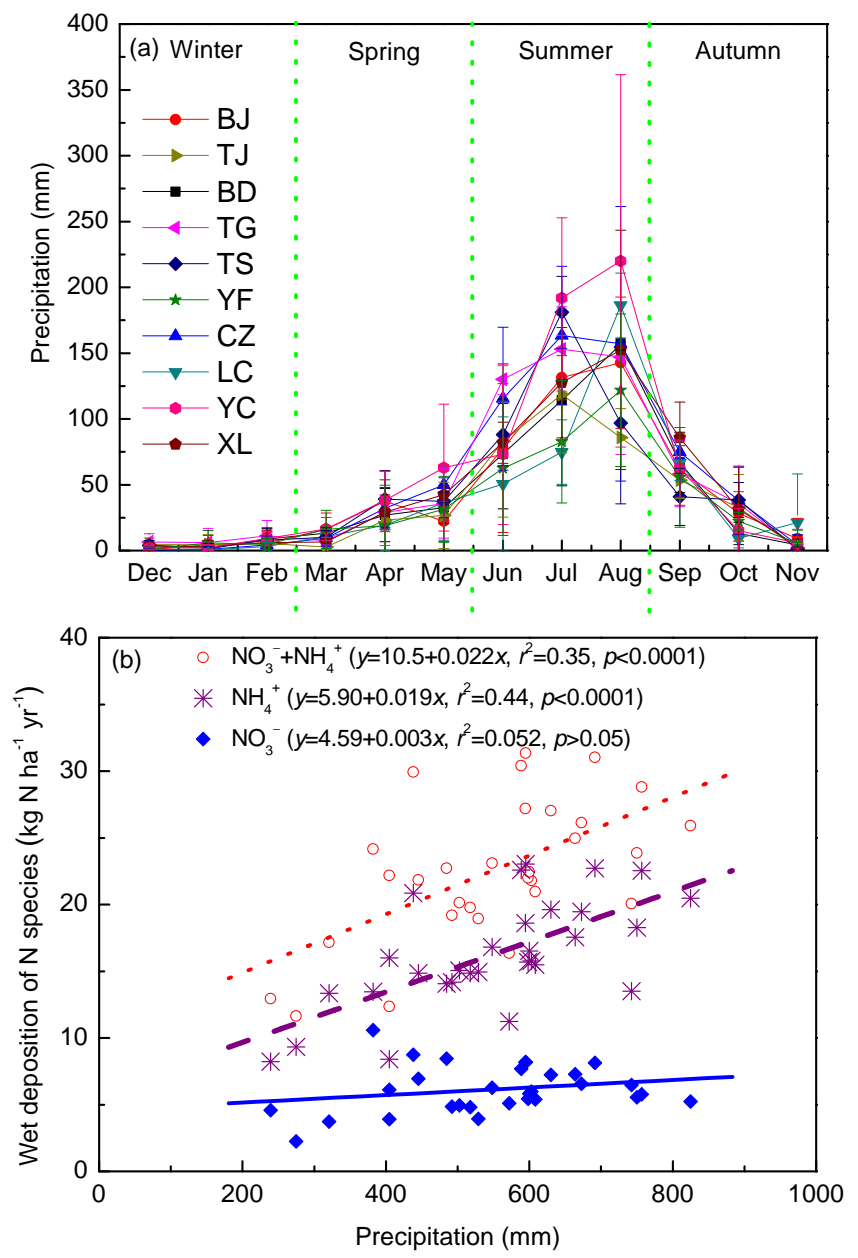

Fig. 4. Seasonal variations of precipitation at the ten selected sites (a) and the annual precipitation against wet deposition of nitrogen in Northern China (b). The seasonal precipitation data are the monthly mean \pm standard deviations of three-year observations (from December 2007 to November 2010). The definition of the site codes is found in the caption of Fig. 1.

and its suburban YF site (May and June) had high values relative to most sites (Fig. 3b). This result further reflects the effects of $\mathrm{NO}_{\mathrm{x}}$ emissions from industry and transportation in urban areas. However, when compared with values at the other sites, the ${ }_{\mathrm{w}} \mathrm{NH}_{4}^{+}$and ${ }_{\mathrm{w}} \mathrm{NO}_{3}^{-}$values were especially elevated in June at the TG site, which was likely the result of local anthropogenic sources.

\subsubsection{Anthropogenic influence on $\mathrm{NO}_{3}^{-}$in precipitation}

To determine the sources of $\mathrm{NO}_{3}^{-}$in precipitation, we performed a preliminary inspection of scatter plots of $\mathrm{NO}_{3}^{-}$vs. $\mathrm{SO}_{4}^{2-}$, which are major contributors to precipitation acidity (Wang et al., 2012). The results revealed that their relationships were reasonably explained by linear models at each site $\left(0.56<r^{2}<0.94, p<0.001\right)$, indicating some similarities 
in the sources and sinks of these species (Arimoto et al., 1996). This can be due to the fact that in China a large part of $\mathrm{NO}_{3}^{-}$comes from coal combustion, which is the major source of $\mathrm{SO}_{4}^{2-}$ (Zhang, Q. et al., 2009). However, the sources for atmospheric $\mathrm{NO}_{3}^{-}$are considerably more diverse than $\mathrm{SO}_{4}^{2-}$, especially in urban areas where the contribution from vehicle emission cannot be ignored (Huebert et al., 1988). Following previous studies (Huebert et al., 1988; Arimoto et al., 1996; Yao et al., 2002), the mass ratio of $\mathrm{NO}_{3}^{-}$to $\mathrm{SO}_{4}^{2-}$ $\left(\mathrm{NO}_{3}^{-} / \mathrm{SO}_{4}^{2-}\right)$ was used as an indicator to investigate the relative importance of stationary vs. mobile sources of sulfur (S) and $\mathrm{N}$ in wet deposition, and two interesting results were found. One was that the annual $\mathrm{NO}_{3}^{-} / \mathrm{SO}_{4}^{2-}$ ratio was lower than 1 among all of the sites, revealing that stationary source emissions are still the important contributor to these compounds in precipitation in Northern China (Yao et al., 2002). Of note is also the fact that the average annual $\mathrm{NO}_{3}^{-} / \mathrm{SO}_{4}^{2-}$ ratio varied from 0.36 to 0.58 among sites possibly caused by differences in emissions. The ratio was highest at the BJ, YF and XL sites, suggesting these sites received relatively more emissions from vehicles than other sites. In contrast, lower ratio was recorded at TS, YC, LC and CZ sites due to predominant $\mathrm{SO}_{2}$ emissions from coal-based power plants, industry and residential heating. However, the $\mathrm{NO}_{3}^{-} / \mathrm{SO}_{4}^{2-}$ ratio may increase in the near future, because the trend of $\mathrm{SO}_{2}$ emissions would be stable and $\mathrm{NO}_{\mathrm{x}}$ emissions from the transport sector, especially in mega cites, will keep on rising (Zhao, Y. et al., 2009). In Beijing, for example, the $\mathrm{NO}_{3}^{-} / \mathrm{SO}_{4}^{2-}$ ratio increased rapidly from 0.24 to 0.58 during 1981-2010 (Wang et al., 2012). If this trend continues, it can be expected that the contribution of mobile sources to $\mathrm{NO}_{3}^{-}$ in precipitation will be enhanced in the coming decades.

\subsection{Dry deposition flux of particulate $\mathrm{N}$ species}

\subsubsection{Spatial variations of ${ }_{p} I N$}

The largest mean annual ${ }_{\mathrm{p}} \mathrm{IN}$ during the period from 2008 to 2010 was observed at the LC site $\left(7.1 \mathrm{~kg} \mathrm{Nha}^{-1} \mathrm{yr}^{-1}\right)$ followed by the BD, TS, YC and $\mathrm{CZ}$ sites, with values of 6.7, 6.6, 6.5 and $6.5 \mathrm{~kg} \mathrm{Nha}^{-1} \mathrm{yr}^{-1}$, respectively (Fig. 2b). However, differences in the monthly mean values at these sites were not significant $(p>0.05)$. The ${ }_{\mathrm{p}} \mathrm{IN}$ was comparable for the $\mathrm{BJ}, \mathrm{TG}$, TJ and YF sites, with values of 5.6, $5.4,5.2$ and $5.1 \mathrm{~kg} \mathrm{Nha}^{-1} \mathrm{yr}^{-1}$, respectively; the monthly mean values at these sites were also not significantly different $(p>0.05)$. The lowest annual mean flux was observed at the $\mathrm{XL}$ site $\left(4.2 \mathrm{~kg} \mathrm{Nha}^{-1} \mathrm{yr}^{-1}\right)$, and this result was attributed to the site's rural characteristics. The monthly mean values at this site differed significantly from those at the other sites $(p<0.05)$ with the exception of YF. In general, $\mathrm{NH}_{4}^{+}(29-$ $72 \%$ of $\left.{ }_{\mathrm{p}} \mathrm{IN}\right)$ and $\mathrm{NO}_{3}^{-}\left(27-70 \%\right.$ of $\left.{ }_{\mathrm{p}} \mathrm{IN}\right)$ were the predominant species in the ${ }_{\mathrm{p}} \mathrm{IN}$, whereas the contribution of $\mathrm{NO}_{2}^{-}$ was negligible (less than $11 \%$ of ${ }_{\mathrm{p}} \mathrm{IN}$ ). $\mathrm{NH}_{4}^{+}$was the primary species at most of the sites with the exception of BJ, TJ, TS and YF (Fig. 2b).

\subsubsection{Seasonal variations of ${ }_{p} I N$}

During the three-year period, the monthly mean dry deposition flux of particulate $\mathrm{N}$ species ranged from 0 to $1.1 \mathrm{~kg} \mathrm{Nha}^{-1}$ month$^{-1}$ for $\mathrm{NH}_{4}^{+}$and from 0 to $1.8 \mathrm{~kg} \mathrm{~N} \mathrm{ha}^{-1}$ month $^{-1}$ for $\mathrm{NO}_{3}^{-}$(Fig. 3c, d). For most sites, the particulate dry deposition flux of $\mathrm{NH}_{4}^{+}\left(\mathrm{p}_{\mathrm{N}} \mathrm{NH}_{4}^{+}\right)$was higher in the winter than in the other seasons, which corresponded to the period of dry season with lower precipitation in the target areas. The ${ }_{\mathrm{p}} \mathrm{NH}_{4}^{+}$was lower in August than in the other months, probably as a result of efficient wet deposition. Compared with ${ }_{\mathrm{p}} \mathrm{NH}_{4}^{+}$, the particulate dry deposition flux of $\mathrm{NO}_{3}^{-}\left(\mathrm{pNO}_{3}^{-}\right)$showed a different seasonal variation with a lower flux in the winter than in the other seasons. The ${ }_{\mathrm{p}} \mathrm{NO}_{3}^{-}$was notably higher in July, August and September at the BJ site. This pattern was different from that observed at the TS site, where the ${ }_{\mathrm{p}} \mathrm{NO}_{3}^{-}$peaked in September, October and November, at the TJ, TG, YC and YF sites, where a higher ${ }_{\mathrm{p}} \mathrm{NO}_{3}^{-}$was observed during April and June, and at the $\mathrm{XL}$ and $\mathrm{CZ}$ sites, where the highest ${ }_{\mathrm{p}} \mathrm{NO}_{3}^{-}$occurred in October. The ${ }_{\mathrm{p}} \mathrm{NO}_{3}^{-}$was elevated in June at the TG site, which was similar to the wet deposition trend.

\subsubsection{Seasonal variations of ${ }_{\mathrm{p}} \mathrm{NO}_{3}^{-} \mathrm{vs.} \mathrm{NO}_{3}^{-}$ concentrations in coarse particles}

From the above analysis, it can be seen that the ${ }_{\mathrm{p}} \mathrm{NO}_{3}^{-}$tend to be lower during the winter and higher in other seasons. Compared with $\mathrm{NO}_{3}^{-}$, however, the ambient concentrations of $\mathrm{NO}_{3}^{-}$in $\mathrm{PM}_{2.5}$ and $\mathrm{PM}_{10}$ in the target areas presented a different seasonal change pattern peaking in winter (Zhang et al., 2012; Wang et al., 2005). This difference is not surprising, because the majority of the dry-deposited $\mathrm{NO}_{3}^{-}$results from coarse particles (Holsen and Noll, 1992; Lestari et al., 2003). Therefore, the seasonal variation of ${ }_{\mathrm{p}} \mathrm{NO}_{3}^{-}$is expected to be highly correlated to the concentration of $\mathrm{NO}_{3}^{-}$ in coarse particulate matter, considering the fact that the seasonal cycle of $V_{\mathrm{d}}$ of coarse particles was not evident (NhoKim et al., 2004). This hypothesis is confirmed by our previous size-resolved compositional analysis shown in Fig. 2d, which illustrates that the concentration of $\mathrm{NO}_{3}^{-}$in coarse particles with a diameter larger than $2.1 \mu \mathrm{m}$ was higher in summer than in winter (Sun, 2011). The size distribution of $\mathrm{NO}_{3}^{-}$ in particles was greatly affected by temperature and relative humidity (Guo et al., 2010), which may favor the formation of coarse mode $\mathrm{NO}_{3}^{-}$in warm months, and thus the higher values of ${ }_{\mathrm{p} O} \mathrm{NO}_{3}^{-}$in summer and fall. Although some interpretations for the seasonal variations of dry-deposited $\mathrm{NO}_{3}^{-}$ have been given, more evidence is needed to prove this. 


\subsubsection{Partition of particulate dry-deposited $\mathbf{N}$ sources}

The molar $\mathrm{NH}_{4}^{+} / \mathrm{NO}_{3}^{-}$ratio was also calculated to investigate the relative contribution of agriculture vs. industry and transportation contributions to the dry deposition of particulate $\mathrm{N}$ species (Fig. 2b). Relative to wet deposition, industry and transportation emissions appeared to have a greater impact on the composition of dry-deposited particulate N. Several points may support the view. First, the spatial variations of ${ }_{\mathrm{p}} \mathrm{NH}_{4}^{+}$and ${ }_{\mathrm{p}} \mathrm{NO}_{3}^{-}$differed, thereby indicating different sources. Second, the $\mathrm{NH}_{4}^{+} / \mathrm{NO}_{3}^{-}$ratio at each site was lower than that of wet deposition. Third, $\mathrm{NO}_{3}^{-}$played a greater role than $\mathrm{NH}_{4}^{+}$in ${ }_{\mathrm{p}} \mathrm{IN}$ at the $\mathrm{BJ}$, TJ, TS and YF sites, where the $\mathrm{NH}_{4}^{+} / \mathrm{NO}_{3}^{-}$was less than 1 . This result is not surprising, because these sites are strongly affected by $\mathrm{NO}_{\mathrm{x}}$ emissions from industry and transportation. The chemical composition of dry-deposited particulate $\mathrm{N}$ was different from the wetdeposited form at these sites, thus reflecting the intense perturbation of the atmospheric $\mathrm{N}$ cycle by anthropogenic activities. However, the ratio was greater than 1 at the $\mathrm{BD}, \mathrm{LC}, \mathrm{CZ}$, YC, TG and XL sites, which indicates that particulate $\mathrm{NH}_{4}^{+}$ from agriculture and human and animal excrement was the major contributor to $\mathrm{IN}$. The $\mathrm{NH}_{4}^{+} / \mathrm{NO}_{3}^{-}$ratio at the $\mathrm{YC}$ and LC sites reached 2.6, which is twice that of the remaining four sites and implies that the ${ }_{\mathrm{p}} \mathrm{IN}$ value in the agricultural regions was mainly dominated by $\mathrm{NH}_{3}$ from agricultural activities and not by $\mathrm{NO}_{\mathrm{x}}$ from industrial activities. This finding agrees with the wet deposition results for agricultural regions.

\subsubsection{Particulate dry-deposited N species vs. composition of particulate matter}

It has been found in previous studies that the contribution of $\mathrm{NO}_{3}^{-}$to $\mathrm{PM}_{2.5}$ and $\mathrm{PM}_{10}$ is larger than that of $\mathrm{NH}_{4}^{+}$, whereas in terms of $\mathrm{N}$, the concentration of $\mathrm{NH}_{4}^{+}-\mathrm{N}$ is larger than $\mathrm{NO}_{3}^{-}-\mathrm{N}$ in both $\mathrm{PM}_{2.5}$ and $\mathrm{PM}_{10}$ (Wang et al., 2005; He et al., 2001). However, the components of dry-deposited $\mathrm{N}$ at the BJ, TJ, TS and YF sites do not coincide with these studies. This inconsistency is not surprising, because large particles play a significant role in dry deposition flux due to their $V_{\mathrm{d}}$. For example, it was found that the majority of the total flux for particulate mass and both $\mathrm{SO}_{4}^{2-}$ and $\mathrm{NO}_{3}^{-}$is due to coarse particles (Holsen and Noll, 1992; Lestari et al., 2003). Therefore, the composition of dry-deposited particles is expected to be in agreement with the coarse particulate matter. In our previous size-resolved compositional analysis (Sun, 2011), the concentration of $\mathrm{NH}_{4}^{+}-\mathrm{N}$ is observed to be lower than $\mathrm{NO}_{3}^{-}-\mathrm{N}$ in coarse particles with a diameter larger than $2.1 \mu \mathrm{m}$ at the BJ, TJ and TS sites; however, at the BD site in winter, the reverse is true (Fig. 2d).This finding coincides with the present studies at these sites on dry-deposited $\mathrm{N}$ components. To improve current understanding of the relationship between coarse particles and deposited $\mathrm{N}$ species, more observation of size-resolved chemical analysis of particulate matter alongside with dry depositions in Northern China is necessary.

It should be noted that $\mathrm{NH}_{4}^{+}$played a greater role than $\mathrm{NO}_{3}^{-}$in ${ }_{\mathrm{p}} \mathrm{IN}$ at most of the sites with the exception of $\mathrm{BJ}$, TJ, TS and YF (Fig. 2b). At these four sites the contribution of $\mathrm{NH}_{4}^{+}-\mathrm{N}$ is lower than $\mathrm{NO}_{3}^{-}-\mathrm{N}$ in particulate $\mathrm{N}$ dry deposition. This cannot be attributed simply to $\mathrm{NH}_{3}$ evaporation during the sampling period, because the volatilization of $\mathrm{NH}_{4}^{+}$in this study could be a systematic error for all the ten sites and not limited to a few sites. As discussed above, we suggest that the relatively high molar ratio of $\mathrm{NH}_{4}^{+} / \mathrm{NO}_{3}^{-}$ at these four sites was attributed to the enhanced contribution of $\mathrm{NO}_{3}^{-}$. This conclusion is reasonable, since these industrial and urban sites are strongly affected by $\mathrm{NO}_{\mathrm{x}}$ emissions from consumption of fossil fuel. This can be further supported by the measurements that $\mathrm{NO}_{3}^{-}$in particles had a larger coarse mode in polluted urban areas of Beijing than its upwind rural site (Guo et al., 2010).

\subsection{Dry deposition flux of gaseous $\mathbf{N}$ species}

\subsubsection{Spatial variations of ${ }_{g} I N$}

The spatial variations of the mean annual ${ }_{\mathrm{g}} \mathrm{IN}$ between 2008 and 2010 are presented in Fig. 2c. The results show relatively high ${ }_{\mathrm{g}} \mathrm{IN}$ at the coastal TG site $\left(66.8 \mathrm{~kg} \mathrm{Nha}^{-1} \mathrm{yr}^{-1}\right)$ and the two agricultural sites, YC and LC (39.3 and $46.3 \mathrm{~kg} \mathrm{Nha}^{-1} \mathrm{yr}^{-1}$, respectively); relatively low values were observed at the suburban YF site and the rural XL site (16.7 and $8.1 \mathrm{~kg} \mathrm{Nha}^{-1} \mathrm{yr}^{-1}$, respectively). However, the ${ }_{\mathrm{g}} \mathrm{IN}$ was approximately equal at the $\mathrm{BD}, \mathrm{BJ}, \mathrm{CZ}, \mathrm{TJ}$ and TS sites, with values of $28.5,25.7,29.8,28.9$ and $31.7 \mathrm{~kg} \mathrm{Nha}^{-1} \mathrm{yr}^{-1}$, respectively. In general, the annual mean ${ }_{\mathrm{g}} \mathrm{IN}$ values at the TG and LC sites were significantly higher than those at the other eight sites $(p<0.05)$. In contrast, the annual mean ${ }_{\mathrm{g}} \mathrm{IN}$ values were significantly lower at the rural XL and suburban YF sites than those at the other eight sites $(p<0.05)$, which is indicative of fewer sources of emissions.

The year-to-year variations in the annual average ${ }_{g} \mathrm{IN}$ were comparatively small at each site with the exception of XL, which showed significantly lower values in 2008 than in 2009 or $2010(p<0.05)$. Although differences between the three years are not significant at the 0.05 level at most of the sites, it is important to point out that ${ }_{\mathrm{g}} \mathrm{NO}_{2}$ appears to slightly increase year by year except for TJ and TS. The overall average ${ }_{\mathrm{g} \mathrm{NO}}$ at the ten sites was $22 \%$ higher in 2010 than 2008. On the other hand, the inter-annual trend of ${ }_{\mathrm{g}} \mathrm{NH}_{3}$ is more ambiguous than that of ${ }_{\mathrm{g} N O}$ at most of the sites, yet the overall average ${ }_{\mathrm{g}} \mathrm{NH}_{3}$ was $8 \%$ higher in 2010 than 2008 . Our finding is consistent with the increasing trend of $\mathrm{NO}_{\mathrm{x}}$ and $\mathrm{NH}_{3}$ emissions in recent years due to increasing fossil fuel combustion and agricultural activities, respectively (Zhao et al., 2008). However, interpreting the relationship 
between emissions and deposition of $\mathrm{N}$ without long-term measurements is challenging.

Overall, the average gaseous dry deposition of $\mathrm{N}$ species in Northern China based on the ten sites was $32.2 \mathrm{~kg} \mathrm{Nha}^{-1} \mathrm{yr}^{-1}$ during the period from 2008 to 2010. More than $91 \%(84-97 \%)$ of this total was attributed to $\mathrm{NH}_{3}$, thereby indicating that $\mathrm{NH}_{3}$ played a more significant role than $\mathrm{NO}_{\mathrm{x}}$ in the ${ }_{\mathrm{g}} \mathrm{IN}$ for agricultural, rural, suburban and even urban sites. For example, the gaseous dry deposition flux of $\mathrm{NH}_{3}\left(\mathrm{gNH}_{3}\right)$ at the $\mathrm{LC}$ and YC sites was 23 times higher than that at the urban and industrial sites (BD, $\mathrm{TJ}, \mathrm{BJ}$ and TS), whereas the gaseous dry deposition flux of $\mathrm{NO}_{2}\left(\mathrm{gNO}_{2}\right)$ at these two agricultural sites was comparable to or lower than at the other sites. The relatively high ${ }_{\mathrm{g}} \mathrm{NH}_{3}$ at the LC and YC sites mainly resulted from local emissions during agricultural activities. Farmers typically apply about $500 \mathrm{~kg} \mathrm{Nha}^{-1} \mathrm{yr}^{-1}$ as $\mathrm{N}$ fertilizer to achieve high yields of maize and wheat in this region. Of the applied $\mathrm{N}$ fertilizer, however, less than $30 \%$ will be absorbed by the crops and more than $20 \%$ (ca. $100 \mathrm{~kg} \mathrm{Nha}^{-1} \mathrm{yr}^{-1}$ ) is lost by $\mathrm{NH}_{3}$ emission (Shen et al., 2009). This makes a significant contribution to high ${ }_{\mathrm{gNH}}$ in agricultural regions.

\subsubsection{Seasonal variations of $\mathrm{g} I N$}

The monthly mean dry deposition flux of gaseous $\mathrm{N}$ species during the three-year period ranged from 0.06 to $10.4 \mathrm{~kg} \mathrm{Nha}^{-1}$ month $^{-1}$ for $\mathrm{NH}_{3}$ and from 0.02 to

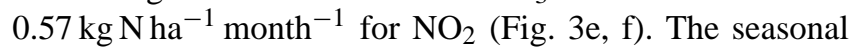
variations of $\mathrm{gNO}_{2}$ were similar at most sites, with higher values observed between May and October, relating to the variations of $V_{\mathrm{d}}$ (Fig. 5d, discussed below). At the XL site, however, the seasonal distribution of $\mathrm{gNO}_{2}$ was not distinct, because its concentration was constant throughout the entire year (Fig. 5c, discussed below). As presented in Fig. 3e, the seasonal trends of ${ }_{\mathrm{gNH}} \mathrm{NH}_{3}$ at most sites, with the exception of TG, did not significantly differ. All sites showed notable peaks in the summer months (July or August) and lower values in the spring, autumn and winter.

The ${ }_{\mathrm{g} N H}$ for the TG site in the winter, spring and autumn were significantly elevated relative to the summer values. This finding is different from the other locations, including the urban TJ site. Although the model-estimated $V_{\mathrm{d}}$ from the TJ and TG sites were comparable, the flux estimates were significantly different because of differences in the concentration measurements. This result is supported by the mean $\mathrm{NH}_{3}$ concentrations at the TG site, which were 3.3-, 2.4-, 1.6- and 2.9-times higher than those at the TJ site during the winter, spring, summer and autumn, respectively (Fig. 5a, discussed below). These high $\mathrm{NH}_{3}$ values at the TG site throughout the year are indicative of complex local emissions from industry, agriculture and other human activities. The difference in $\mathrm{NH}_{3}$ concentrations between the TG and $\mathrm{TJ}$ sites was smaller in the summer than in other seasons, because $\mathrm{NH}_{3}$ at the TG site can be readily converted to $\mathrm{NH}_{4}^{+}$in the summer as a result of the higher relative humidity of the coastal area and wet deposition near the source (Fig. 2a).

\subsubsection{Seasonal variations of $V_{d}$ for gaseous $N$ species}

Although $\mathrm{NH}_{3}$ played a greater role than $\mathrm{NO}_{\mathrm{x}}$ in ${ }_{\mathrm{g}} \mathrm{IN}$ in Northern China (Fig. 2c), the mean annual molar ratio of gaseous concentrations of $\mathrm{NH}_{3}$ to $\mathrm{NO}_{2}$ was lower than 1 at most sites with the exception of YC and LC, thereby indicating that fossil fuel combustion was a dominant factor influencing the concentrations of gaseous $\mathrm{N}$ in the air. However, the gas dry deposition flux was determined by both the concentrations and $V_{\mathrm{d}}$. Even the measured concentrations of $\mathrm{NH}_{3}$ and $\mathrm{NO}_{2}$ were comparable; the flux estimates can be significantly different because of differences in the modelestimated $V_{\mathrm{d}}$.

To give a detailed interpretation for the variations of ${ }_{\mathrm{g}} \mathrm{IN}$, $V_{\mathrm{d}}$ and concentrations of $\mathrm{N}$ species are presented in Fig. 5. It can be seen that the mean monthly $V_{\mathrm{d}}$ of $\mathrm{NH}_{3}$ and $\mathrm{NO}_{2}$ modeled for the three years fall in the range of 3.9-19.8 and $0.2-1.7 \mathrm{~mm} \mathrm{~s}^{-1}$, respectively. Note that $\mathrm{NO}$ was negligible in the ${ }_{\mathrm{g}} \mathrm{IN}$ (Fig. 2c), since NO is largely an emitted species and its $V_{\mathrm{d}}$ is in the range of $0.2-0.6 \mathrm{~mm} \mathrm{~s}^{-1}$. The present $V_{\mathrm{d}}$ data compare well with those from a number of previous studies (Marner and Harrison, 2004; Endo et al., 2010; Yang et al., 2010; Zhang, L. et al., 2009; Hanson and Lindberg, 1991), and provide enhanced spatial and temporal resolution for this area (Fig. 5b, d).

The seasonal variations of $V_{\mathrm{d}}$ for $\mathrm{NO}_{2}$ were similar at each site, with higher values simulated in summer. Considering the weaker seasonal variations of $\mathrm{NO}_{2}$ concentrations, the seasonality of $\mathrm{gNO}_{2}$ is a function of $V_{\mathrm{d}}$. Compared with $R_{\mathrm{a}}$ and $R_{\mathrm{b}}, R_{\mathrm{c}}$ is a significant factor determining $V_{\mathrm{d}}$ of $\mathrm{NO}_{2}$ (Wesely and Hicks, 2000). The canopy or surface resistance describes the uptake process at the surface and in turn is dependent on the vegetative characteristics of the underlying surface, with smaller $R_{\mathrm{c}}$ for surfaces with stronger uptake (Mathur and Dennis, 2003). Therefore, the seasonal variation of $V_{\mathrm{d}}$ for $\mathrm{NO}_{2}$ was primarily caused by differences in surface conditions. Compared to $\mathrm{NO}_{2}$, the dry deposition of $\mathrm{NH}_{3}$ to most surfaces is a relatively efficient removal process (Sutton et al., 1994); the canopy resistance to $\mathrm{NH}_{3}$ uptake is much lower than $R_{\mathrm{a}}$ and $R_{\mathrm{b}}$. Thus, $R_{\mathrm{a}}$ and $R_{\mathrm{b}}$, parameterized mainly by the wind speed, are dominant factors. The enhanced $V_{\mathrm{d}}$ of $\mathrm{NH}_{3}$ in winter and early spring may result from decreased $R_{\mathrm{a}}$ at high wind speeds in cold seasons, which is more pronounced in sites nearest mountainous and coastal areas, such as XL, YF, TJ, and TG. However, seasonal variations of $V_{\mathrm{d}}$ for $\mathrm{NH}_{3}$ did not coincide with ${ }_{\mathrm{g}} \mathrm{NH}_{3}$, suggesting ambient concentration was the determinant of $\mathrm{gNH}_{3}$.

\subsubsection{Seasonal variations of gaseous $\mathbf{N}$ concentrations}

The mean monthly concentrations of $\mathrm{N}$ species measured for the three years ranged from 0.2 to $45.2 \mu \mathrm{g} \mathrm{N} \mathrm{m}^{-3}$ for $\mathrm{NH}_{3}$ and 

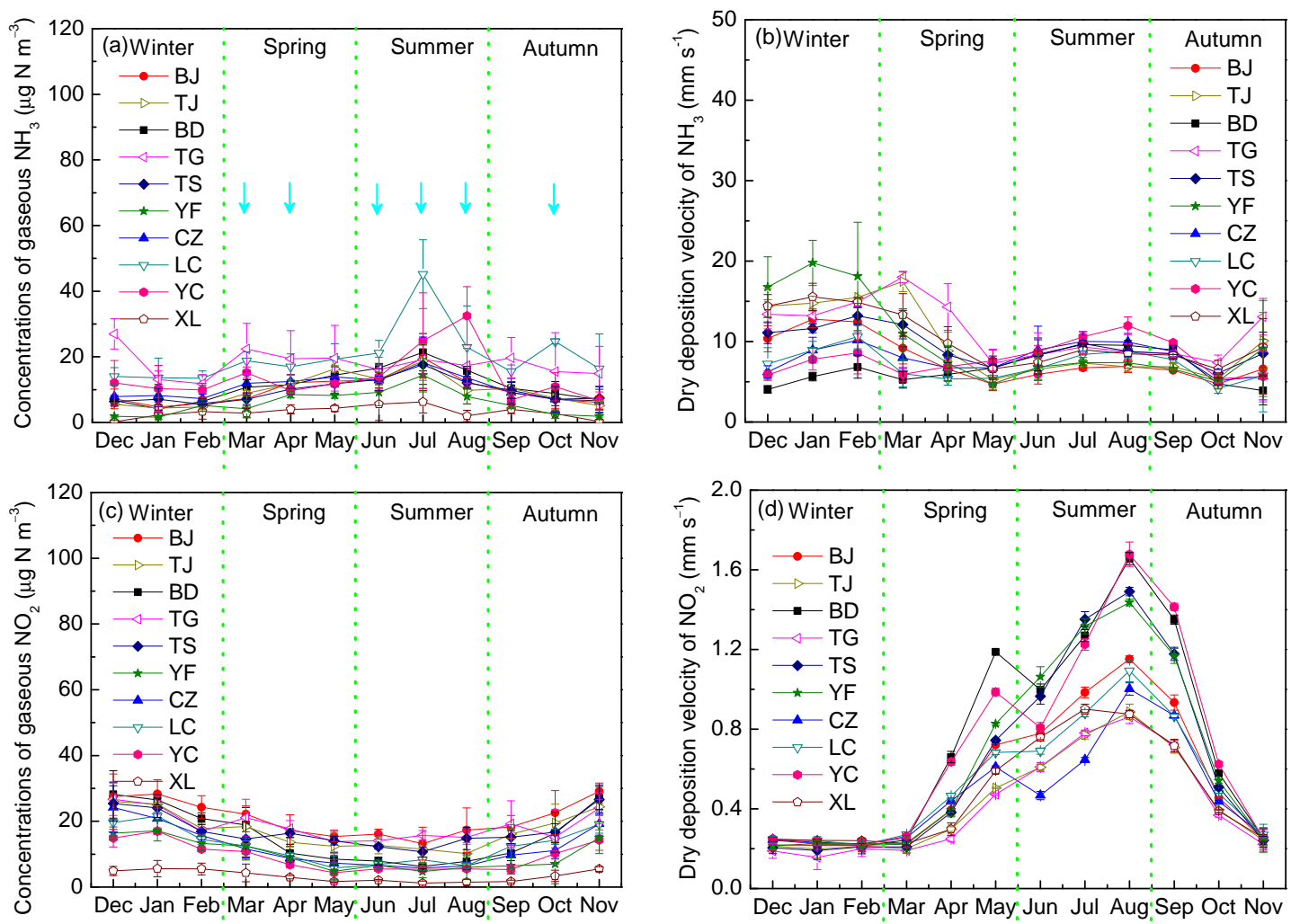

Fig. 5. Seasonal variations of the concentrations and dry deposition velocity of gaseous nitrogen species at the ten selected sites in Northern China. The data shown are the monthly mean \pm standard deviations of three-year observations (from December 2007 to November 2010 ). The arrow denotes the timing of $\mathrm{N}$ fertilizer application for maize and wheat in agricultural regions of the YC and LC sites (a). The definition of the site codes is found in the caption of Fig. 1.

from 1.2 to $29.1 \mu \mathrm{g} \mathrm{N} \mathrm{m}^{-3}$ for $\mathrm{NO}_{2}$ (Fig. 5a, c). These results are comparable to the findings of previous measurements in China (Meng et al., 2010, 2011; Shen et al., 2009; Yang et al., 2010). $\mathrm{NO}_{2}$ concentrations have weaker seasonal variations, because they mainly come from industrial and transportation emissions that have less of a seasonal cycle (Zhang, Q. et al., 2009). The relatively high value of $\mathrm{NO}_{2}$ in late autumn and winter corresponds with peak emissions from home heating in Northern China. Concentration of $\mathrm{NO}_{2}$ at the XL site was consistently lower, reflecting the remoteness of the monitoring site.

Unlike $\mathrm{NO}_{2}$, a seasonal pattern of $\mathrm{NH}_{3}$ concentrations with a summer maximum was identified at all sites with the exception of TG. Although the volatilization of $\mathrm{NH}_{3}$ in the field was sufficient to justify high $\mathrm{gNH}_{3}$ in agricultural regions, the source of $\mathrm{NH}_{3}$ at a given site is expected to be influenced by a broader area than just local emissions. Thus, the relatively high $\mathrm{NH}_{3}$ in summer could be a result of agriculture and human and animal excrement in the target areas. This conclusion is supported by the correlation between the seasonal variation of gaseous $\mathrm{NH}_{3}$ concentrations and emissions, both of which are closely related to the timing of fertilization (Fig. 5a) and seasonal changes of temperature (Zhang et al., 2011; Shen et al., 2011). Additionally, the $\mathrm{NH}_{3}$ emissions from vehicles in urban areas could also contribute to the observed summer maximum (Ianniello et al., 2010).

Site TG displayed generally higher $\mathrm{NH}_{3}$ concentrations than those sites in industrial and agricultural areas. There was no obvious seasonal change at this site, although the values were lower in January and February. The main source at this site is likely to have been some unknown industrial emissions relating to human activities. This can be partially supported by the fact that $\mathrm{NH}_{3}$ concentrations in January and February are lower than in neighboring months, because of reduced industrial activity during the Chinese Spring Festival holiday.

\subsection{Total atmospheric deposition of $\mathbf{N}$ species}

\subsubsection{Total atmospheric $\mathrm{N}$ deposition in Northern China}

The current measurements obtained in this study allowed us to systematically evaluate the total (wet plus dry) deposition flux of IN ( $\left.{ }_{t} \mathrm{IN}\right)$ in Northern China. Previous studies only focused on either the wet or the dry deposition of individual $\mathrm{N}$ species (Shen et al., 2009; Zhang et al., 2008a). Although ten sites are far from enough to make clear the distribution of $\mathrm{N}$ deposition in Northern China, which is a very large 
area, the monitoring has been the most comprehensive one in China till now, especially including dry deposition. The mean annual ${ }_{\mathrm{t}} \mathrm{IN}$ ranged from 28.5 to $100.4 \mathrm{~kg} \mathrm{Nha}^{-1} \mathrm{yr}^{-1}$ over the three-year sampling period at the ten sites (Table 2). The spatial variation of ${ }_{\mathrm{t}} \mathrm{IN}$ was similar to that of gaseous deposition; the values at the $\mathrm{BJ}, \mathrm{TJ}, \mathrm{BD}, \mathrm{TS}$ and $\mathrm{CZ}$ sites were higher than those at the XL and YF sites and lower than those at the YC, LC and TG sites. The seasonal variations of ${ }_{t} \mathrm{IN}$ were also similar to those of the gaseous deposition; higher values were observed in the summer (not shown). As stated previously, the $\mathrm{g}_{\mathrm{g}}$ was different from year to year at each site, and there was a slight increasing trend for dry deposition from 2008 to 2010. Yet, as the year-to-year variations of ${ }_{\text {w }}$ IN showed no consistent trend, the inter-annual variations of ${ }_{t} \mathrm{IN}$ were more ambiguous.

The overall mean ${ }_{t} \mathrm{IN}$ in Northern China was $60.6 \pm$ $19.6 \mathrm{~kg} \mathrm{~N} \mathrm{ha}^{-1} \mathrm{yr}^{-1}$ during the three-year period. This value was significantly higher than previous estimates of the total $\mathrm{N}$ deposition in the target area, which ranged from 13 to $20 \mathrm{~kg} \mathrm{~N} \mathrm{ha}^{-1} \mathrm{yr}^{-1}$ (Lü and Tian, 2007). This discrepancy was attributed to their omission of certain species, such as $\mathrm{NH}_{3}$, from the synthesis of the observational data. Arithmetic average values for the whole region are not good enough, since the sites represent different areas. However, the results, which show extremely high values, are of great importance. When arranged by land use types, the highest ${ }_{t} \mathrm{IN}$ in this study was found at the agricultural sites, with an average of $73.1 \mathrm{~kg} \mathrm{Nha}^{-1} \mathrm{yr}^{-1}$. This value was lower than the total airborne $\mathrm{N}$ input into the agro-ecosystems in the North China Plain, which was estimated to be $83.3 \mathrm{~kg} \mathrm{Nha}^{-1} \mathrm{yr}^{-1}$ using the integrated total $\mathrm{N}$ input (ITNI) system (He et al., 2007). The relatively high values estimated by the ITNI system are not surprising, because the $\mathrm{N}$ deposition estimates from this system vary with both the plant development phase and species of crops (Russow and Böhme, 2005). In addition, the ${ }_{\mathrm{t}} \mathrm{IN}$ in this study was likely underestimated, because certain components, such as $\mathrm{HNO}_{3}$, were not measured. However, their inclusion is not expected to significantly increase the total deposition because of their limited contribution (Shen et al., 2009).

The overall mean ${ }_{\mathrm{t}} \mathrm{IN}$ in industrial sites was $72.9 \mathrm{~kg} \mathrm{Nha}^{-1} \mathrm{yr}^{-1}$ during the three-year period, second only to agricultural sites and followed by urban, suburban and rural sites, with average values of 55.7, 50.6 and $28.5 \mathrm{~kg} \mathrm{~N} \mathrm{ha}^{-1} \mathrm{yr}^{-1}$, respectively. Although it is difficult to compare with other studies type by type, due to the fact that the measurement data in Northern China are lacking, the relatively high values in other land use types than rural areas are possibly a result of increased $\mathrm{N}$ emissions. Since there are no serious local emissions within $100 \mathrm{~km}$, the XL site was usually considered as a background station to understand the regional air pollution in Northern China (Xin et al., 2010). Similarly, the estimated ${ }_{t} I N$ in the XL site can be used as a reference to characterize the current $\mathrm{N}$ deposition in Northern China. Considering that the estimated value of the XL site was several times higher than that observed by CASTNET, EMEP and EANET (Endo et al., 2010), N deposition in the target areas was extremely high. Because nation-wide emissions of reactive $\mathrm{N}$ will continue to rise, Northern China was estimated to receive the maximum $\mathrm{N}$ deposition values by the CMAQ simulations (Zhao, Y. et al., 2009). Therefore, it is important to evaluate the effects of increasing $\mathrm{N}$ deposition on different ecosystems in Northern China.

\subsubsection{Potential effects of $\mathbf{N}$ deposition in Northern China}

The effects of $\mathrm{N}$, such as acidification and eutrophication, are mainly related to natural ecosystems and can be evaluated using critical loads. For forest and grassland in this area where the $\mathrm{N}$ deposition may be relatively low, comparison of critical loads to deposition derived from urban and agricultural areas may overestimate the effects of N. To primarily evaluate the potential risk of $\mathrm{N}$ deposition in Northern China, we compared the critical loads for temperate forests to $\mathrm{N}$ deposition levels derived from the XL site, which is located in a forest area and surrounded by few villages. Although the ${ }_{\mathrm{t}} \mathrm{IN}$ at the XL site $\left(28.5 \mathrm{~kg} \mathrm{~N} \mathrm{ha}^{-1} \mathrm{yr}^{-1}\right)$ are within the range of empirical critical loads $\left(10-60 \mathrm{~kg} \mathrm{~N} \mathrm{ha}^{-1} \mathrm{yr}^{-1}\right.$ ) for certain temperate forests in the northern part of China (Liu et al., 2010), they reach the highest critical loads calculated from the steady state mass balance in the target areas (15-30 $\mathrm{kg} \mathrm{N} \mathrm{ha}^{-1} \mathrm{yr}^{-1}$ ) (Duan et al., 2001). This result raises concerns regarding the harmful biological and chemical effects on ecosystems, including physiological variations, reduced biodiversity, elevated nitrate leaching, and changes in soil microorganisms (Liu et al., 2010).

Besides natural ecosystems, the detrimental effects of $\mathrm{N}$ deposition in many other types, such as agricultural ecosystems and water bodies, should be taken into account. Although $\mathrm{N}$ deposition is an important nutrient resource in the agricultural areas (He et al., 2007), it may also result in the enhanced emissions of nitrous oxide $\left(\mathrm{N}_{2} \mathrm{O}\right)$ (Zhang et al., 2011), which is an important greenhouse gas. Moreover, coastal waters near industrial regions, such as Bohai Bay, may receive greater $\mathrm{N}$ loads from atmospheric deposition and are susceptible to eutrophication (Barile and Lapointe, 2005; He et al., 2011); e.g., the ${ }_{t} \mathrm{IN}$ at the coastal industrial TG site reached $100.4 \mathrm{~kg} \mathrm{Nha}^{-1} \mathrm{yr}^{-1}$. Thus, the potential risks of heavy $\mathrm{N}$ deposition on sensitive terrestrial and aquatic ecosystems should be controlled to within acceptable levels by substantially reducing the amount of reactive $\mathrm{N}$ emitted into the atmosphere.

Numerical models are useful tools to address these concerns, but a major problem of using this approach is that observed data to validate the models are often lacking, thereby hampering accurate estimation of $\mathrm{N}$ deposition in the target area. Northern China is considered to be one of the main "hot reference spots" of atmospheric pollution in East Asia 
Table 2. Contribution of different pathways and species to the estimated total $\mathrm{N}$ deposition $\left(\mathrm{kg} \mathrm{Nha}^{-1} \mathrm{yr}^{-1}\right)$ in Northern China.

\begin{tabular}{|c|c|c|c|c|c|c|c|}
\hline \multirow{2}{*}{ Location } & \multirow{2}{*}{ Site } & \multirow{2}{*}{ Total $\mathrm{N}$ deposition } & \multirow{2}{*}{ Wet } & \multicolumn{2}{|c|}{ Dry } & \multirow{2}{*}{ Reduced N } & \multirow{2}{*}{ Oxidized $\mathrm{N}$} \\
\hline & & & & Particle & Gas & & \\
\hline \multirow[t]{2}{*}{ Urban } & $\mathrm{BJ}$ & $59.2(5.7) \mathrm{b}$ & $47.1 \%$ & $9.5 \%$ & $43.4 \%$ & $72.1 \%$ & $27.9 \%$ \\
\hline & $\mathrm{TJ}$ & $52.2(5.6) \mathrm{b}$ & $34.7 \%$ & $9.9 \%$ & $55.4 \%$ & $78.4 \%$ & $21.6 \%$ \\
\hline \multirow{3}{*}{ Industrial } & $\mathrm{BD}$ & $58.3(2.8) \mathrm{b}$ & $39.6 \%$ & $11.5 \%$ & $48.9 \%$ & $79.0 \%$ & $21.0 \%$ \\
\hline & TG & $100.4(14.4) \mathrm{a}$ & $28.1 \%$ & $5.4 \%$ & $66.5 \%$ & $86.7 \%$ & $13.3 \%$ \\
\hline & TS & $59.9(3.7) \mathrm{b}$ & $36.0 \%$ & $11.1 \%$ & $52.9 \%$ & $77.9 \%$ & $22.1 \%$ \\
\hline \multirow[t]{2}{*}{ Suburban } & YF & $42.4(7.0) \mathrm{c}$ & $48.8 \%$ & $11.9 \%$ & $39.3 \%$ & $70.6 \%$ & $29.4 \%$ \\
\hline & $\mathrm{CZ}$ & $58.8(6.0) \mathrm{b}$ & $38.3 \%$ & $11.0 \%$ & $50.7 \%$ & $82.1 \%$ & $17.9 \%$ \\
\hline \multirow[t]{2}{*}{ Agricultural } & $\mathrm{LC}$ & $75.5(6.1) \mathrm{a}$ & $29.3 \%$ & $9.4 \%$ & $61.3 \%$ & $87.5 \%$ & $12.5 \%$ \\
\hline & YC & $70.7(12.0) \mathrm{b}$ & $35.1 \%$ & $9.2 \%$ & $55.7 \%$ & $86.7 \%$ & $13.3 \%$ \\
\hline Rural & XL & $28.5(3.5) \mathrm{c}$ & $57.0 \%$ & $14.8 \%$ & $28.2 \%$ & $72.2 \%$ & $27.8 \%$ \\
\hline \multicolumn{2}{|c|}{ 10-site average } & $60.6(19.6)$ & $39.4 \%$ & $10.4 \%$ & $50.2 \%$ & $79.3 \%$ & $20.7 \%$ \\
\hline
\end{tabular}

Standard deviations are in parentheses. Different letters in the "Total N deposition" column indicate significant differences between the sites at $p<0.05$. The definition of the site codes is found in the caption of Fig. 1.

due to the rapid development. Therefore, ten monitoring sites were chosen with varying urban geographies, energy structures and ecosystem types to provide regional information on $\mathrm{N}$ deposition in this region. Although the present investigation is far from clearing up all aspects of $\mathrm{N}$ deposition in Northern China, it adds substantially to the existing knowledge about the character and amount of the atmospheric $\mathrm{N}$ deposition to the surrounding environment. Most important, the present observations are very useful to better constrain the emission inventory and atmospheric chemistry models in this part of the world. In future research, we will use models (e.g., CMAQ) to address the variations of $\mathrm{N}$ deposition and its impact on various areas, not only on urban, rural and agricultural regions but also on forests, grasslands and coastal water bodies in China. We believe the land use area weighted value is better than the arithmetic average flux of $\mathrm{N}$ deposition for the whole region. Except for the land surfaces, however, the spatio-temporal variations of $\mathrm{N}$ deposition in Northern China are also dependent on the changing emissions and meteorology conditions. All of these factors will be considered in future modeling work.

\subsubsection{Contribution of different pathways to total $\mathrm{N}$ deposition}

The dry deposition of gaseous $\mathrm{N}$ species was the primary contributor to ${ }_{t} \mathrm{IN}$ at most sites, and the contribution ranged from $28 \%$ (XL) to $67 \%$ (TG), averaging $50 \%$. The mean annual ${ }_{\mathrm{g}} \mathrm{IN}$ ranged from 8.1 to $66.8 \mathrm{~kg} \mathrm{Nha}^{-1} \mathrm{yr}^{-1}$, with a mean of $32.6 \mathrm{~kg} \mathrm{Nha}^{-1} \mathrm{yr}^{-1}$ during the three-year period. The ${ }_{\mathrm{g}} \mathrm{IN}$ was higher at the agricultural sites, YC and LC, and the industrial site, TG. Given the influence of local $\mathrm{NH}_{3}$ emissions from intensive fertilization (Table 1), it is not surprising that the ${ }_{\mathrm{g}} \mathrm{IN}$ at the agricultural LC site reached $44.5 \mathrm{~kg} \mathrm{Nha}^{-1} \mathrm{yr}^{-1}$. However, the significantly higher ${ }_{\mathrm{g}} \mathrm{IN}$ at the coastal TG site could be attributable to the influence of reactive $\mathrm{N}$ emissions from anthropogenic sources (see above). The influence of fertilization could also explain why the agricultural YC site had a higher ${ }_{\mathrm{g}} \mathrm{IN}$ than the other industrial locations, including $\mathrm{BD}, \mathrm{TJ}$ and $\mathrm{TS}$; regardless the difference was not significant $(p>0.05)$. The average value of ${ }_{\mathrm{g} I N}$ at the two agricultural sites LC and YC was $42.8 \mathrm{~kg} \mathrm{Nha}^{-1} \mathrm{yr}^{-1}$. This value agrees with the sum of the annual ${ }_{\mathrm{gNH}}$ and $\mathrm{gNO}_{2}$ (approximately $40 \mathrm{~kg} \mathrm{~N} \mathrm{ha}^{-1} \mathrm{yr}^{-1}$ ) that was previously estimated for agricultural regions in China, but it is significantly higher than values from other agricultural areas in the world (Shen et al., 2009; Hu et al., 2007). With the exception of the TG, LC, YF and XL sites, no clear differences were found among the other six sites where the average ${ }_{\mathrm{g}} \mathrm{IN}$ was $30.5 \mathrm{~kg} \mathrm{Nha}^{-1} \mathrm{yr}^{-1}$, which is approximately 7-times higher than the values reported by EMEP and EANET (Endo et al., 2010).

The wet deposition contributed $28-57 \%$ to the ${ }_{\mathrm{t}} \mathrm{IN}$ with a mean of $40 \%$, which was $10 \%$ lower than ${ }_{\mathrm{g}} \mathrm{IN}$. The average ${ }_{w} \mathrm{IN}$ at ten sites in Northern China was $22.6 \mathrm{~kg} \mathrm{~N} \mathrm{ha}^{-1} \mathrm{yr}^{-1}$ between 2008 and 2010. This is approximately 5-times greater than the values reported by CASTNET, EMEP and EANET (Endo et al., 2010). The estimated ${ }_{\mathrm{w}} \mathrm{IN}$ values are also greater than those reported for most areas of China except for the Yangtze River Basin, where the average is $27 \mathrm{~kg} \mathrm{~N} \mathrm{ha}^{-1} \mathrm{yr}^{-1}$ (Xie et al., 2008; Zhao, X. et al., 2009).

Compared with ${ }_{w} \mathrm{IN}$ and ${ }_{\mathrm{g}} \mathrm{IN}$, the proportion of ${ }_{\mathrm{p}} \mathrm{IN}$ to the ${ }_{t} \mathrm{IN}$ was relatively small, ranging from $5 \%$ to $15 \%$ and averaging $10 \%$. The mean annual $\mathrm{p}$ IN ranged from 4.2 to $7.1 \mathrm{~kg} \mathrm{Nha}^{-1} \mathrm{yr}^{-1}$, with a mean of $5.9 \mathrm{~kg} \mathrm{Nha}^{-1} \mathrm{yr}^{-1}$ during the three-year period. This result is comparable to values from the North China Plain (1.3-9.6 $\mathrm{kg} \mathrm{N} \mathrm{ha}^{-1} \mathrm{yr}^{-1}$ ), obtained as the difference between the bulk and wet-only deposition (Zhang et al., 2008a), values from Southeast China (3.4-7.6 kg N ha ${ }^{-1} \mathrm{yr}^{-1}$ ), which were estimated using a water-surrogate surface (Chen et al., 2006), and 
values from other areas around the world, such as Singapore $\left(5.9 \mathrm{~kg} \mathrm{Nha}^{-1} \mathrm{yr}^{-1}\right)$ (He et al., 2011) and Japan ( $5 \mathrm{~kg} \mathrm{~N} \mathrm{ha}^{-1} \mathrm{yr}^{-1}$ ) (Endo et al., 2010), which were estimated using the inferential method.

Precipitation, particulate and gas dry deposition of $\mathrm{N}$ accounted for $40 \%, 10 \%$ and $50 \%$ of the total $\mathrm{N}$ deposition in Northern China, respectively. To our knowledge, the only other simultaneous determination of these three pathways in China showed that the largest sources of atmospheric $\mathrm{N}$ to the forest ecosystem in South China were gases $(64 \%)$, followed by rainwater $(25 \%)$ and particles $(11 \%)$ (Hu et al., 2007). The results from this study suggest that wet deposition cannot be used alone to determine the total deposition, because the total flux may be underestimated if the dry deposition of certain species or pathways is not considered. Because dry deposition in both the particulate and gaseous phase is an important contribution to total $\mathrm{N}$ deposition, additional research is needed to refine the quantities of dry deposition flux. This present study is a significant step in this direction.

\subsubsection{Comparison with emission estimates of $\mathrm{NH}_{\mathrm{x}}$ and $\mathrm{NO}_{\mathrm{y}}$}

Compared with the ${ }_{\mathrm{p}} \mathrm{IN}$, both ${ }_{\mathrm{w}} \mathrm{IN}$ and ${ }_{\mathrm{g}} \mathrm{IN}$ are major contributors to the ${ }_{\mathrm{t}} \mathrm{IN}$ at most sites. Because the ${ }_{\mathrm{g}} \mathrm{IN}$ and ${ }_{\mathrm{w}} \mathrm{IN}$ are dominated by $\mathrm{NH}_{3}$ and $\mathrm{NH}_{4}^{+}$, the reduced $\mathrm{N}$ species $\left(\mathrm{NH}_{\mathrm{x}}\right)$ was found to contribute $71-88 \%$ of the ${ }_{\mathrm{t}} \mathrm{IN}$, whereas the oxidized species $\left(\mathrm{NO}_{\mathrm{y}}\right)$ constituted only $12-29 \%$ (Table 2). This finding indicates that $\mathrm{N}$ deposition is dependent not only on the pathway but also on the chemical form, thereby further highlighting the need to better resolve the relative contribution of oxidized and reduced forms of $\mathrm{N}$ in regulation strategies.

Importantly, the field-based evidence from this study can be used to validate the emission data and has significant implications for policy-makers that are attempting to control atmospheric pollution in Northern China. The mean annual deposition flux of $\mathrm{NH}_{\mathrm{x}}$ and $\mathrm{NO}_{\mathrm{y}}$ during the three-year period was categorized into five grades and plotted on the maps showing the spatial distribution of emissions for the corresponding gases (Fig. 6a, c).

$\mathrm{NH}_{\mathrm{x}}$ deposition at the rural $\mathrm{XL}$ site was the lowest (20.6 $\mathrm{kg} \mathrm{N} \mathrm{ha}^{-1} \mathrm{yr}^{-1}$ ) of all the sites, which is consistent with the regional background characteristics of the site (Fig. 6a). The emission data shown in Fig. 6a reveal a little amount of $\mathrm{NH}_{3}$ emissions over the vast mountainous areas to the north and west of Beijing. The $\mathrm{NH}_{\mathrm{x}}$ deposition values at the suburban YF site $\left(30.0 \mathrm{~kg} \mathrm{Nha}^{-1} \mathrm{yr}^{-1}\right)$ were higher than those at the XL site, which was possibly a result of human activities. In contrast, the highest $\mathrm{NH}_{\mathrm{x}}$ deposition flux $\left(87.0 \mathrm{~kg} \mathrm{~N} \mathrm{ha}^{-1} \mathrm{yr}^{-1}\right)$ was found at the TG site, which is not surrounded by large $\mathrm{NH}_{3}$ emission sources (Fig. 6a), thus indicating that the inventory did not adequately account for $\mathrm{NH}_{3}$ emissions from some unknown industrial sources. The second highest $\mathrm{NH}_{\mathrm{x}}$ deposition values were observed at the
LC site $\left(66.1 \mathrm{~kg} \mathrm{Nha}^{-1} \mathrm{yr}^{-1}\right)$, followed by the YC, CZ, TS, $\mathrm{BD}, \mathrm{BJ}$ and TJ sites, with values of $61.3,48.3,46.7,46.1$, 42.7 and $40.9 \mathrm{~kg} \mathrm{Nha}^{-1} \mathrm{yr}^{-1}$, respectively. Overall, the spatial pattern of $\mathrm{NH}_{\mathrm{x}}$ deposition reflected changes in $\mathrm{NH}_{3}$ emission sources (Fig. 6b).

The extent of spatial variability of $\mathrm{NO}_{\mathrm{y}}$ deposition (Fig. 6c) was not as large as that of $\mathrm{NH}_{\mathrm{x}}$ (Fig. 6a), possibly because $\mathrm{NO}_{\mathrm{x}}$ has fewer natural emission sources than $\mathrm{NH}_{3}$. Similar to $\mathrm{NH}_{\mathrm{x}}$, the lowest $\mathrm{NO}_{\mathrm{y}}$ deposition values (7.9 $\mathrm{kg} \mathrm{Nha}^{-1} \mathrm{yr}^{-1}$ ) were also observed at the rural XL site, as a result of fewer anthropogenic emissions. This difference in sources could also explain why the agricultural sites YC and LC had relatively low $\mathrm{NO}_{\mathrm{y}}$ deposition levels compared with the suburban sites $\mathrm{CZ}$ and $\mathrm{YF}$. However, $\mathrm{NO}_{\mathrm{y}}$ deposition was much higher in the urban and industrial areas, including $\mathrm{BJ}, \mathrm{BD}, \mathrm{TG}$ and TS, where power plant, industry and transportation emissions of $\mathrm{NO}_{\mathrm{x}}$ were also larger than in the surrounding regions, as shown in Fig. 6c. $\mathrm{NO}_{\mathrm{y}}$ deposition was significantly higher at the site of $\mathrm{BJ}$ than $\mathrm{TJ}$, whereas $\mathrm{NO}_{\mathrm{x}}$ emissions were lower at $\mathrm{BJ}$ than $\mathrm{TJ}$ (Fig. 6d). Because the $\mathrm{BJ}$ site is close to roads, vehicle emissions may be the major source of $\mathrm{NO}_{\mathrm{x}}$, and these emissions may be underestimated in existing gridded inventories.

The spatial patterns of observed $\mathrm{NH}_{\mathrm{x}}$ and $\mathrm{NO}_{\mathrm{y}}$ deposition compare well with $\mathrm{NH}_{3}$ and $\mathrm{NO}_{\mathrm{x}}$ emissions, respectively. It has been noted elsewhere (Zhao et al., 2008) that $\mathrm{NO}_{\mathrm{x}}$ and $\mathrm{NH}_{3}$ tend to increase in relation to human activity, and such a pattern was identified here. Additionally, $\mathrm{NH}_{3}$ emissions were greater than those of $\mathrm{NO}_{\mathrm{x}}$ in large areas (Fig. 6a, c), which agrees with the field-based evidence mentioned above. Although the magnitudes of the emissions were not necessarily proportional to the measurements of deposition (Fig. 6b, d), the applicability of the emissions data cannot be discounted. If combined with deposition data, emissions inventory can be used to distinguish approximate regional differences in reactive $\mathrm{N}$ pollution and help policy-makers implement source control decisions. To mitigate atmospheric $\mathrm{N}$ deposition in Northern China and its potential ecological impacts, reactive $\mathrm{N}$ emissions, especially $\mathrm{NH}_{3}$ surrounding the BJ, TS and LC sites, must be abated.

\subsection{Uncertainty analysis and future research needs}

\subsubsection{Uncertainties in estimation of ${ }_{w}$ IN}

Since wet deposition was measured directly and gaseous dry deposition was estimated based on modeled $V_{\mathrm{d}}$, the reported ${ }_{\mathrm{w}} \mathrm{IN}$ is more accurate than the ${ }_{\mathrm{g}} \mathrm{IN}$. However, some light rain events were not sampled due to malfunctions of the rainfall sampler lid. Of the total number of precipitation samples, $16 \%$ were discarded from final analysis due to low volumes $(<20 \mathrm{ml})$ that did not permit a complete chemical analysis. Thus, these missed samples may result in an underestimation of ${ }_{w}$ IN during the observation period. Clearly, if all of the 

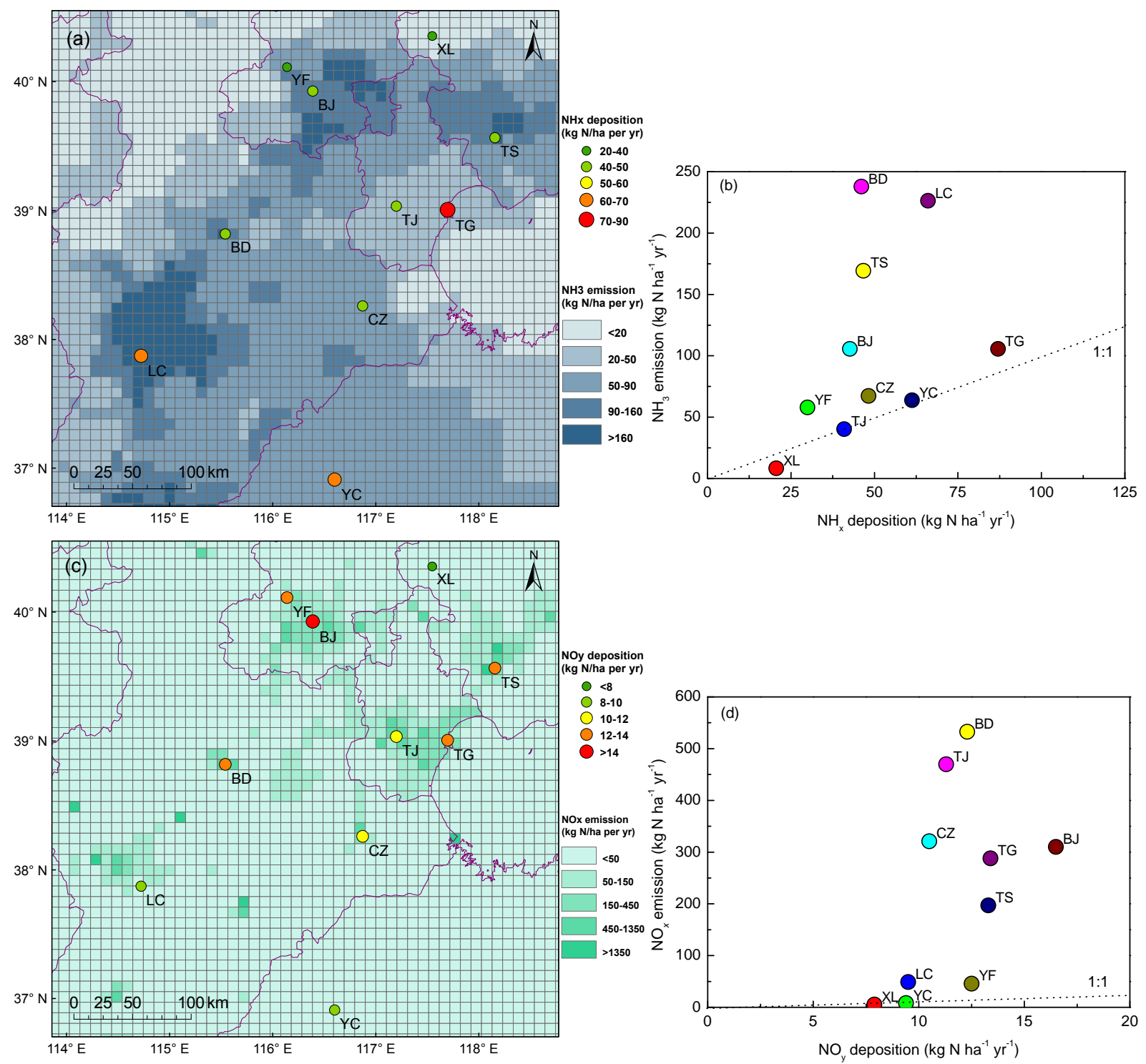

Fig. 6. Spatial variations of the atmospheric nitrogen deposition flux with emissions distribution in Northern China. The deposition data of $\mathrm{NO}_{\mathrm{y}}$ (oxidized nitrogen) and $\mathrm{NH}_{\mathrm{x}}$ (reduced nitrogen) are the annual means of three-year observations (from December 2007 to November 2010). The emission data of $\mathrm{NO}_{\mathrm{x}}$ and $\mathrm{NH}_{3}$ are from 2008, with a resolution of $9 \times 9 \mathrm{~km}^{2}$. The definition of the site codes is found in the caption of Fig. 1.

samples were included in the dataset, then the assessment of ${ }_{\text {w }}$ IN could be more precise.

\subsubsection{Uncertainties in estimation of ${ }_{p}$ IN}

To date, there is still no generally acceptable technology for sampling and analyzing particulate dry depositions. Therefore, there have been insufficient data to reliably estimate and understand ${ }_{\mathrm{p}} \mathrm{IN}$. The throughfall method was usually applied to provide an estimate of the total deposition to forest soils, including dry deposition, by measuring the amount and composition of rain water passing through a forest canopy. However, several problems were also related to this approach as summarized by previous work (Draaijers et al., 1996; Balestrini et al., 2007). Additionally, this method was confined to ecosystems with vegetation (e.g., forest and grass) and not suitable for urban surfaces and water bodies where vegetation is lacking. Previous studies have found that a bucket collected more dry-deposited material than Teflon, foil or coated foil surfaces (Dasch, 1985). Recently, a PUF filter-based surrogate surface was placed in the glass bucket to successfully collect the dry-deposited airborne particles for trace metal analysis (Pan et al., 2010b). The method can avoid particle bounce and is relatively inexpensive and simple; it can be used at a variety of locations and over varying 
time intervals to delineate spatial and temporal information. The method was used in this study to estimate ${ }_{\mathrm{p}} \mathrm{IN}$. For large particles, gravitational settling is a major component that can be sampled with this method. Studies have shown, however, it is difficult to capture fine particles, because the impaction and interception of particles are important for vegetative canopies, and their effects are not reproduced in the design of any standardized artificial collection device (Wesely and Hicks, 2000). Therefore, the estimation of the drydeposited particles in this study has potential uncertainties and may provide an estimation of the lower limit for ${ }_{\mathrm{p}} \mathrm{IN}$.

Additionally, measuring the particles $\mathrm{NH}_{4}^{+}$and $\mathrm{NO}_{3}^{-}$is known to be plagued with problems due to the semi-volatility in the form of $\mathrm{NH}_{4} \mathrm{NO}_{3}$ (Lestari et al., 2003). In previous studies, the concentrations of particulate $\mathrm{NO}_{3}^{-}$collected by the weekly filter pack were $7 \%$ lower than those by the annular denuder system (Sickles et al., 1999). Even the two existing North American inferential dry deposition networks, CASTNET and CAPMoN, have known measurement uncertainties due to the volatilization of the particle $\mathrm{NH}_{4} \mathrm{NO}_{3}$, and large uncertainties in the flux estimates due to differences in their respective inferential models (Dentener et al., 2009). Since the dry-deposited particles in this study were collected at ambient temperatures for a relatively long sampling period, artifacts cannot be prevented due to volatilization of some reactive $\mathrm{N}$ species, especially $\mathrm{NH}_{4}^{+}$and $\mathrm{NO}_{3}^{-}$in summer, and ${ }_{\mathrm{p}} \mathrm{IN}$ could probably be underestimated.

\subsubsection{Uncertainties in estimation of $\mathrm{g} I \mathrm{~N}$}

Measurements of gas dry deposition are technically challenging and expensive, so modeled $V_{\mathrm{d}}$ are paired with measured concentrations to estimate ${ }_{\mathrm{g}} \mathrm{IN}$ in this study. However, all models entail a degree of uncertainty and this study is no exception. Due to many factors, including incompleteness of observations, uncertainties in chemistry schemes and sparseness of measurements, modeled dry deposition fluxes are very uncertain and can seldom be compared to measurements (Pleim and Ran, 2011). For example, $\mathrm{NH}_{3}$ exhibits distinctly bi-directional behavior, where it alternately deposits and emits on diurnal, seasonal, or sometimes longer time scales, yet CMAQ v4.6 is not able to model this real-world phenomenon. Additionally, the current model works with outdated land cover databases, because land cover in recent years was not available. Furthermore, the underlying surface parameters (e.g., albedo and surface roughness length) used in CMAQ were on the basis of early measurements in Europe and the US and may be different from China, possibly leading to large inconsistencies.

Although it is important to understand the dominance of these factors on the $V_{\mathrm{d}}$ variations, it still remains unclear how accurate the model is due to a paucity of measurements. Even for ozone dry deposition, which is the most widely measured substance, current model results still show substantial errors compared to observations (Pleim and Ran, 2011). Since the experimental data to confirm the calculated resistances for the large areas meant to be addressed are not available, uncertainties are difficult to quantify (Endo et al., 2010; Wesely, 1989). In a previous comparison of models, relative uncertainties for weekly estimates of $V_{\mathrm{d}}$ computed for selected gases for selected areas in the eastern US are approximately $\pm 30 \%$ (Wesely, 1989). Uncertainties in $V_{\mathrm{d}}$ modeling can be reduced if field measurements provide constraints on parameterizations, but that is beyond the scope of this paper. To refine the quantities of dry deposition flux, follow-on field experiments will focus on comparisons of the modeling-based results against $\mathrm{NH}_{3}$ flux measured by eddy covariance, considering $\mathrm{NH}_{3}$ contributes a larger fraction of the reactive $\mathrm{N}$ budget.

\subsubsection{Effects of the stomatal compensation point on $\mathrm{NH}_{3}$ deposition}

$\mathrm{NH}_{3}$ is subject to a bi-directional flux over $\mathrm{N}$-rich ecosystems and the net direction of this flux is often uncertain. To determine the direction of the $\mathrm{NH}_{3}$ flux, a so-called compensation point $\left(C_{0}\right)$ was introduced in previous studies (Massad et al., 2010; Sutton et al., 1998). The bi-directional exchange flux of $\mathrm{NH}_{3}\left(F_{\mathrm{NH}_{3}}\right)$ is defined as

$F_{\mathrm{NH}_{3}}=\left(C_{\text {air }}-C_{0}\right) V_{\mathrm{d}}$.

Deposition occurs when $C_{0}$ is below the ambient concentrations of $\mathrm{NH}_{3}\left(C_{\text {air }}\right)$, otherwise emission occurs. $C_{0}$ is not available in the present study; for simplification, $C_{0}$ was assumed to be $5 \mu \mathrm{g} \mathrm{N} \mathrm{m}{ }^{-3}$ under a crop canopy (Denmead et al., 2008). When $C_{0}$ was set as zero, $F_{\mathrm{NH}_{3}}$ was equal to the flux deposited only (i.e., the $\mathrm{NH}_{3}$ compensation point was not taken into account in the flux calculation). The deposition flux of $\mathrm{NH}_{3}\left(F_{\mathrm{NH}_{3}}^{\prime}\right)$ is then given by

$F_{\mathrm{NH}_{3}}^{\prime}=C_{\text {air }} V_{\mathrm{d}}$.

Therefore, the ratio of $C_{0} / C_{\text {air }}$ can be used as an index to evaluate the degree influenced by use and non-use of bidirectional exchange. Using the three-year mean concentrations of $\mathrm{NH}_{3}$ at the YC and LC (14.0 and $\left.20.1 \mu \mathrm{g} \mathrm{N} \mathrm{m}^{-3}\right)$ sites, $C_{0} / C_{\text {air }}$ at these two sites was estimated to be 0.36 and 0.25 , respectively. This result indicated that $\mathrm{gNH}_{3}$ would decrease $36 \%$ and $25 \%$ if $\mathrm{NH}_{3}$ emission from the vegetation was considered, declining from 37.3 to 24.0 and from 44.1 to $33.1 \mathrm{~kg} \mathrm{~N} \mathrm{ha}^{-1} \mathrm{yr}^{-1}$ at the $\mathrm{YC}$ and LC sites, respectively. Thus, the ${ }_{\mathrm{gNH}} \mathrm{NH}_{3}$ estimated for the two sites in Figs. $2 \mathrm{c}$ and $3 \mathrm{e}$ should be treated as the high-end values. Ignoring the bidirectional $\mathrm{NH}_{3}$ exchange is unlikely to significantly overestimate the total flux, but will result in misleading spatial variation of that flux. Additional work is required to evaluate bi-directional $\mathrm{NH}_{3}$ exchange more thoroughly over agricultural areas, in the context of the stomatal compensation point, as well as an extension of this framework to the whole region. 


\section{Conclusions}

Although uncertainties existed in the current estimation of atmospheric $\mathrm{N}$ deposition, this is the first time such an experiment-based work has been applied to quantify the individual $\mathrm{N}$ species deposited via precipitation (wet deposition) and as gases and particles (dry deposition) simultaneously in Northern China. This unique dataset provides field-based evidence that the total $\mathrm{N}$ deposition is significantly higher than previous estimates in the target area and in other regions of the world, thus prompting concerns regarding ecological impacts. We consider that the results presented are important not only to inform policy-makers on abatement of pollutant emissions and ecosystem protection but also to initiate further detailed studies. The major results and conclusions are as follows.

1. Clear seasonal variations were observed, although spatial differences in the ${ }_{\mathrm{w}} \mathrm{IN}$ were not significant between the ten sites or in the different years. While the spatial variations of annual ${ }_{w} \mathrm{NH}_{4}^{+}$throughout Northern China can mainly be explained by the precipitation amount, annual ${ }_{\mathrm{w}} \mathrm{NO}_{3}^{-}$was strongly dependent on local emissions from coal burning. $\mathrm{NH}_{4}^{+}$remains the major contributor to wet $\mathrm{N}$ deposition in the target areas, but the contribution of $\mathrm{NO}_{3}^{-}$to ${ }_{\mathrm{w}} \mathrm{IN}$ was enhanced in certain urban areas due to emissions from vehicles.

2. Relative to wet deposition, the intense perturbation of the chemical composition of ${ }_{\mathrm{p}} \mathrm{IN}$ due to fossil fuse combustion was identified in certain urban and industrial sites, where the molar ratio of $\mathrm{NH}_{4}^{+} / \mathrm{NO}_{3}^{-}$was less than 1. The peak values of ${ }_{\mathrm{p}} \mathrm{NO}_{3}^{-}$in summer and autumn and its enhanced contribution to ${ }_{\mathrm{p}} \mathrm{IN}$ at certain sites are supported by the measurements that $\mathrm{NO}_{3}^{-}$had a larger coarse mode in warm months and in polluted areas. The complex relationship between coarse particles and deposited $\mathrm{N}$ species will be a focus of a future study.

3. Unlike ${ }_{p} \mathrm{IN}$, the seasonal and spatial variations of ${ }_{\mathrm{g}} \mathrm{IN}$ were significant. A slight increasing trend of annual ${ }_{\mathrm{g}} \mathrm{NO}_{2}$ and ${ }_{\mathrm{g}} \mathrm{NH}_{3}$ was observed at most sites, which is consistent with their emissions in recent years. Although the measured concentrations of $\mathrm{NH}_{3}$ and $\mathrm{NO}_{2}$ were comparable, $\mathrm{NH}_{3}$ played a more significant role than $\mathrm{NO}_{\mathrm{x}}$ in the annual ${ }_{\mathrm{g}} \mathrm{IN}$ because of relatively high $V_{\mathrm{d}}$. The $V_{\mathrm{d}}$ was also a dominant factor influencing the seasonal variations of ${ }_{\mathrm{g} N O}$. However, the seasonal variation of $\mathrm{gNH}_{3}$ was consistent with the ambient concentration of $\mathrm{NH}_{3}$.

4. The greatest contribution to the ${ }_{t} \mathrm{IN}$ was from ${ }_{\mathrm{g}} \mathrm{IN}$, followed by ${ }_{\mathrm{w}} \mathrm{IN}$ and ${ }_{\mathrm{p}} \mathrm{IN}$. Although there was a slight increasing trend for dry deposition from 2008 to 2010, the inter-annual variations of ${ }_{t} \mathrm{IN}$ were more ambiguous, because the year-to-year variations of ${ }_{w}$ IN showed no consistent trend. The atmospheric deposition flux of $\mathrm{NH}_{\mathrm{x}}$ was greater than that of $\mathrm{NO}_{\mathrm{y}}$. Human activities have greater significant impacts on the deposition of $\mathrm{NO}_{\mathrm{y}}$ than $\mathrm{NH}_{\mathrm{x}}$ at certain urban and industrial sites, which is in agreement with $\mathrm{NH}_{3}$ and $\mathrm{NO}_{\mathrm{x}}$ emission data.

Despite the bias of the current monitoring approach for dry deposition, the results presented in this study clearly demonstrate the importance of the contributions of $\mathrm{NH}_{3}$ to the total $\mathrm{N}$ deposition. To mitigate $\mathrm{N}$ deposition risks to sensitive terrestrial and aquatic ecosystems in Northern China, priority should be given to strategies for bringing $\mathrm{NH}_{3}$ emissions to within acceptable levels. The results also underscore the need to refine total $\mathrm{N}$ deposition measurement over Northern China, in the context of an improved simulation of $V_{\mathrm{d}}$ for the gaseous $\mathrm{N}$ dry deposition, as well as an extension of this framework to the whole country. An alternative method for quantifying bi-directional flux of $\mathrm{NH}_{3}$ using eddy covariance and concentration measurements is underway and will constrain the simulated $V_{\mathrm{d}}$ in evaluating the performance of the atmospheric chemistry models (e.g., CMAQ). Such models are also needed to provide regional-scale deposition maps over long-term periods so that the information can be used to investigate the detrimental effects of $\mathrm{N}$ deposition on various natural ecosystems.

Acknowledgements. This work was supported by the Knowledge Innovation Project of the Chinese Academy of Sciences (No.: KZCX1-YW-06-01), the National Basic Research Program of China (No.: 2012CB417100 and 2007CB407303) and the National Natural Science Foundation of China (No.: 41021004). The authors would like to thank H. Tang, W. Liu, W. Wang, G. Fu, Y. Chang, X. Feng, Y. Cheng, C. Zhang, Z. Liu and other staff at the ten monitoring sites for their cooperation during sample collection. We are indebted to X. Zheng, L. Zhang, Q., Tong, T. Wang, X. Tie and J. Shen for their constructive comments and suggestions. The authors are also grateful to two anonymous reviewers for stimulating a fruitful discussion, due to which some results presented in the discussion version of the paper could be revised and expanded.

Edited by: T. Wang

\section{References}

Arimoto, R., Duce, R., Savoie, D., Prospero, J., Talbot, R., Cullen, J., Tomza, U., Lewis, N., and Rayl, B.: Relationships among aerosol constituents from Asia and the North Pacific during PEM-West A, J. Geophys. Res., 101, 2011-2023, doi:10.1029/95JD01071, 1996.

Balestrini, R., Arisci, S., Brizzio, M. C., Mosello, R., Rogora, M., and Tagliaferri, A.: Dry deposition of particles and canopy exchange: Comparison of wet, bulk and throughfall deposition at five forest sites in Italy, Atmos. Environ., 41, 745-756, doi:10.1016/j.atmosenv.2006.09.002, 2007.

Barile, P. J. and Lapointe, B. E.: Atmospheric nitrogen deposition from a remote source enriches macroalgae in coral reef ecosystems near Green Turtle Cay, Abacos, Bahamas, Mar. Pol- 
lut. Bull., 50, 1262-1272, doi:10.1016/j.marpolbul.2005.04.031, 2005.

Byun, D. W. and Ching, J. K. S.: Science algorithms of the EPA Models-3 community multiscale air quality (CMAQ) modeling system; Report EPA/600/R-99/030; US Environmental Protection Agency: Research Triangle Park, NC, 1999.

Chen, N. W., Hong, H. S., Xiao, J., Zhang, L. P., and Wang, J. P.: Dry deposition of atmospheric nitrogen to Jiulong River watershed in southeast China, Acta Ecologica Sinica, 26, 2602-2067, 2006 (in Chinese).

Clark, H. and Kremer, J. N.: Estimating direct and episodic atmospheric nitrogen deposition to a coastal waterbody, Mar. Environ. Res., 59, 349-366, doi:10.1016/j.marenvres.2004.06.001, 2005.

Costabile, F., Bertoni, G., Desantis, F., Wang, F., Weimin, H., Fenglei, L., and Allegrini, I.: A preliminary assessment of major air pollutants in the city of Suzhou, China, Atmos. Environ., 40, 6380-6395, doi:10.1016/j.atmosenv.2006.05.056, 2006.

Dasch, J. M.: Direct measurement of dry deposition to a polyethylene bucket and various surrogate surfaces, Environ. Sci. Technol., 19, 721-725, doi:10.1021/es00138a011, 1985.

Denmead, O., Freney, J., and Dunin, F.: Gas exchange between plant canopies and the atmosphere: Casestudies for ammonia, Atmos. Environ., 42, 3394-3406, doi:10.1016/j.atmosenv.2007.01.038, 2008.

Dentener, F., Vet, B., Dennis, R., Enza, D., Kulshrestha, U., and Galy-Lacaux, C.: Progress in monitoring and modelling estimates of $\mathrm{N}$ deposition at local, regional and global scales, available at: http://www.initrogen.net/ fileadmin/user_upload/2009_edinburgh/background_documents/ Topic1-Deposition_BackgroundDocument.pdf (last access: 13 July 2012), 2009.

Dise, N. B. and Wright, R. F.: Nitrogen leaching from European forests in relation to nitrogen deposition, Forest Ecol. Manag., 71, 153-161, doi:10.1016/0378-1127(94)06092-W, 1995.

Draaijers, G. P. J., Spranger, T., Erisman, J. W., and Wyers, G. P.: The application of throughfall measurements for atmospheric deposition monitoring, Atmos. Environ., 30, 3349-3361, doi:10.1016/1352-2310(96)00030-1, 1996.

Duan, L., Xie, S., Zhou, Z., Ye, X., and Hao, J.: Calculation and mapping of critical loads for $\mathrm{S}, \mathrm{N}$ and acidity in China, Water Air. Soil Poll., 130, 1199-1204, doi:10.1023/A:1013908629150, 2001.

Endo, T., Yagoh, H., Sato, K., Matsuda, K., Hayashi, K., Noguchi, I., and Sawada, K.: Regional characteristics of dry deposition of sulfur and nitrogen compounds at EANET sites in Japan from 2003 to 2008, Atmos. Environ., 45, 1259-1267, doi:10.1016/j.atmosenv.2010.12.003, 2010.

Fahey, T. J., Williams, C. J., Rooney-Varga, J. N., Cleveland, C. C., Postek, K. M., Smith, S. D., and Bouldin, D. R.: Nitrogen deposition in and around an intensive agricultural district in central New York, J. Environ. Qual., 28, 1585-1600, doi:10.2134/jeq1999.00472425002800050025x, 1999.

Fenn, M. E., Poth, M. A., Aber, J. D., Baron, J. S., Bormann, B. T., Johnson, D. W., Lemly, A. D., McNulty, S. G., Ryan, D. F., and Stottlemyer, R.: Nitrogen excess in North American ecosystems: predisposing factors, ecosystem responses, and management strategies, Ecol. Appl., 8, 706-733, doi:10.2307/2641261, 1998.
Flechard, C. R., Nemitz, E., Smith, R. I., Fowler, D., Vermeulen, A. T., Bleeker, A., Erisman, J. W., Simpson, D., Zhang, L., Tang, Y. S., and Sutton, M. A.: Dry deposition of reactive nitrogen to European ecosystems: a comparison of inferential models across the NitroEurope network, Atmos. Chem. Phys., 11, 2703-2728, doi:10.5194/acp-11-2703-2011, 2011.

Galloway, J. N., Schlesinger, W. H., Hiram Levy, I. I., Michaels, A., and Schnoor, J. L.: Nitrogen fixation: anthropogenic enhancement-environmental response, Global. Biogeochem. Cy, 9, 235-252, doi:10.1029/95GB00158, 1995.

Gruber, N. and Galloway, J. N.: An Earth-system perspective of the global nitrogen cycle, Nature, 451, 293-296, doi:10.1038/nature06592, 2008.

Guo, S., Hu, M., Wang, Z. B., Slanina, J., and Zhao, Y. L.: Sizeresolved aerosol water-soluble ionic compositions in the summer of Beijing: implication of regional secondary formation, Atmos. Chem. Phys., 10, 947-959, doi:10.5194/acp-10-947-2010, 2010.

Guo, Y., Feng, X., Li, Z., He, T., Yan, H., Meng, B., Zhang, J., and Qiu, G.: Distribution and wet deposition fluxes of total and methyl mercury in Wujiang River Basin, Guizhou, China, Atmos. Environ., 42, 7096-7103, doi:10.1016/j.atmosenv.2008.06.006, 2008.

Hanson, P. J. and Lindberg, S. E.: Dry deposition of reactive nitrogen compounds: A review of leaf, canopy and non-foliar measurements, Atmos. Environ., 25, 1615-1634, doi:10.1016/09601686(91)90020-8, 1991.

He, C. E., Liu, X. J., Fangmeier, A., and Zhang, F. S.: Quantifying the total airborne nitrogen input into agroecosystems in the North China Plain, Agr. Ecosyst. Environ., 121, 395-400, doi:10.1016/j.agee.2006.12.016, 2007.

He, J., Balasubramanian, R., Burger, D. F., Hicks, K., Kuylenstierna, J. C. I., and Palani, S.: Dry and wet atmospheric deposition of nitrogen and phosphorus in Singapore, Atmos. Environ., 45, 2760-2768 doi:10.1016/j.atmosenv.2011.02.036, 2011.

He, K., Yang, F., Ma, Y., Zhang, Q., Yao, X., Chan, C. K., Cadle, S., Chan, T., and Mulawa, P.: The characteristics of $\mathrm{PM}_{2.5}$ in Beijing, China, Atmos. Environ., 35, 4959-4970, doi:10.1016/s1352-2310(01)00301-6, 2001.

Hill, K. A., Shepson, P. B., Galbavy, E. S., and Anastasio, C.: Measurement of wet deposition of inorganic and organic nitrogen in a forest environment, J. Geophys. Res., 110, G02010, doi:10.1029/2005jg000030, 2005.

Holsen, T. M. and Noll, K. E.: Dry deposition of atmospheric particles: application of current models to ambient data, Environ. Sci. Technol., 25, 1807-1815, doi:10.1021/es00033a015, 1992.

Hu, Z. Y., Xu, C. K., Zhou, L. N., Sun, B. H., He, Y. Q., Zhou, J., and Cao, Z. H.: Contribution of Atmospheric Nitrogen Compounds to N Deposition in a Broadleaf Forest of Southern China, Pedosphere, 17, 360-365, doi:10.1016/S1002-0160(07)60043-5, 2007.

Huebert, B. J., Wang, M. X., and Lü, W. X.: Atmospheric nitrate, sulfate, ammonium and calcium concentrations in China, Tellus B, 40, 260-269, doi:10.1111/j.1600-0889.1988.tb00296.x, 1988.

Ianniello, A., Spataro, F., Esposito, G., Allegrini, I., Rantica, E., Ancora, M. P., Hu, M., and Zhu, T.: Occurrence of gas phase ammonia in the area of Beijing (China), Atmos. Chem. Phys., 10, 9487-9503, doi:10.5194/acp-10-9487-2010, 2010.

Lü, C. Q. and Tian, H. Q.: Spatial and temporal patterns of nitrogen deposition in China: Synthesis of observational data, J. Geophys. 
Res., 112, D22S05, doi:10.1029/2006JD007990, 2007.

Larssen, T., Lydersen, E., Tang, D., He, Y., Gao, J., Liu, H., Duan, L., Seip, H., Vogt, R., and Mulder, J.: Acid rain in China, Environ. Sci. Technol., 40, 418-425, doi:10.1021/es0626133, 2006.

Lestari, P., Oskouie, A. K., and Noll, K. E.: Size distribution and dry deposition of particulate mass, sulfate and nitrate in an urban area, Atmos. Environ., 37, 2507-2516, doi:10.1016/s13522310(03)00151-1, 2003.

Liu, X., Ju, X., Zhang, Y., He, C., Kopsch, J., and Fusuo, Z.: Nitrogen deposition in agroecosystems in the Beijing area, Agr. Ecosyst. Environ., 113, 370-377, doi:10.1016/j.agee.2005.11.002, 2006.

Liu, X., Duan, L., Mo, J. M., Du, E., Shen, J. L., Lu, X. K., Zhang, Y., Zhou, X. B., He, C. E., and Zhang, F. S.: Nitrogen deposition and its ecological impact in China: An overview, Environ. Pollut., 155, 2251-2264, doi:10.1016/j.envpol.2010.08.002, 2010.

Marner, B. B. and Harrison, R. M.: A spatial refined monitoring based study of atmospheric nitrogen deposition, Atmos. Environ., 38, 5045-5056, doi:10.1016/j.atmosenv.2004.06.016, 2004.

Massad, R. S., Tuzet, A., Loubet, B., Perrier, A., and Cellier, P.: Model of stomatal ammonia compensation point (STAMP) in relation to the plant nitrogen and carbon metabolisms and environmental conditions, Ecol. Model., 221, 479-494, doi:10.1016/j.ecolmodel.2009.10.029, 2010.

Mathur, R. and Dennis, R. L.: Seasonal and annual modeling of reduced nitrogen compounds over the eastern United States: Emissions, ambient levels, and deposition amounts, J. Geophys. Res, 108, 4481, doi:10.1029/2002JD002794, 2003.

Meng, Z. Y., Xu, X. B., Wang, T., Zhang, X. Y., Yu, X. L., Wang, S. F., Lin, W. L., Chen, Y. Z., Jiang, Y. A., and An, X. Q.: Ambient sulfur dioxide, nitrogen dioxide, and ammonia at ten background and rural sites in China during 2007-2008, Atmos. Environ., 44, 2625-2631, doi:10.1016/j.atmosenv.2010.04.008, 2010.

Meng, Z. Y., Lin, W. L., Jiang, X. M., Yan, P., Wang, Y., Zhang, Y. M., Jia, X. F., and Yu, X. L.: Characteristics of atmospheric ammonia over Beijing, China, Atmos. Chem. Phys., 11, 61396151, doi:10.5194/acp-11-6139-2011, 2011.

Nho-Kim, E. Y., Michou, M., and Peuch, V. H.: Parameterization of size-dependent particle dry deposition velocities for global modeling, Atmos. Environ., 38, 1933-1942, doi:10.1016/j.atmosenv.2004.01.002, 2004.

Pan, Y. P., Wang, Y. S., Xin, J. Y., Tang, G. Q., Song, T., Wang, Y. H., Li, X. R., and Wu, F. K.: Study on dissolved organic carbon in precipitation in Northern China, Atmos. Environ., 44, 23502357, doi:10.1016/j.atmosenv.2010.03.033, 2010a.

Pan, Y. P., Wang, Y. S., Yang, Y. J., Wu, D., Xin, J. Y., and Fan, W. Y.: Determination of trace metals in atmospheric dry deposition with a heavy matrix of PUF by inductively coupled plasma mass spectroscopy after microwave digestion, Environ. Sci., 31, 553559, 2010b (in Chinese).

Park, S. U. and Lee, Y. H.: Spatial distribution of wet deposition of nitrogen in South Korea, Atmos. Environ., 36, 619-628, doi:10.1016/S1352-2310(01)00489-7, 2002.

Perrino, C. and Catrambone, M.: Development of a variable-pathlength diffusive sampler for ammonia and evaluation of ammonia pollution in the urban area of Rome, Italy, Atmos. Environ., 38, 6667-6672, doi:10.1016/j.atmosenv.2004.08.032, 2004.

Pleim, J. and Ran, L.: Surface flux modeling for air quality applications, Atmosphere, 2, 271-302, doi:10.3390/atmos2030271,
2011.

Pryor, S. C., Barthelmie, R. J., and Jensen, B.: Nitrogen dry deposition at an AmeriFlux site in a hardwood forest in the MidWest, Geophys. Res. Lett., 26, 691-694, doi:10.1029/1999GL900066, 1999.

Russow, R. and Böhme, F.: Determination of the total nitrogen deposition by the ${ }^{15} \mathrm{~N}$ isotope dilution method and problems in extrapolating results to field scale, Geoderma, 127, 62-70, doi:10.1016/j.geoderma.2004.11.015, 2005.

Sakata, M., Marumoto, K., Narukawa, M., and Asakura, K.: Regional variations in wet and dry deposition fluxes of trace elements in Japan, Atmos. Environ., 40, 521-531, doi:10.1016/j.atmosenv.2005.09.066, 2006.

Schwede, D., Zhang, L., Vet, R., and Lear, G.: An intercomparison of the deposition models used in the CASTNET and CAPMoN networks, Atmos. Environ., 45, 1337-1346 doi:10.1016/j.atmosenv.2010.11.050, 2011.

Shen, J. L., Tang, A. H., Liu, X. J., Fangmeier, A., Goulding, K. T. W., and Zhang, F. S.: High concentrations and dry deposition of reactive nitrogen species at two sites in the North China Plain, Environ. Pollut., 157, 3106-3113, doi:10.1016/j.envpol.2009.05.016, 2009.

Shen, J. L., Liu, X. J., Fangmeier, A., Goulding, K., and Zhang, F. S.: Atmospheric ammonia and particulate ammonium from agricultural sources in the North China Plain, Atmos. Environ., 45, 5033-5041, doi:10.1016/j.atmosenv.2011.02.031, 2011.

Sickles, I. J. E., Hodson, L. L., and Vorburger, L. M.: Evaluation of the filter pack for long-duration sampling of ambient air, Atmos. Environ., 33, 2187-2202, doi:10.1016/s1352-2310(98)00425-7, 1999.

Sun, Y.: Chemical composition and mass closure of particulate matter in Beijing, Tianjin and Hebei megacities, Northern China, Ms thesis, Capital Normal University, Beijing, 69 pp., 2011.

Sutton, M. A., Asman, W. A. H., and Schjørring, J. K.: Dry deposition of reduced nitrogen, Tellus B, 46, 255-273, doi:10.1034/j.1600-0889.1994.t01-2-00002.x, 1994.

Sutton, M. A., Burkhardt, J. K., Guerin, D., Nemitz, E., and Fowler, D.: Development of resistance models to describe measurements of bi-directional ammonia surface-atmosphere exchange, Atmos. Environ., 32, 473-480, doi:10.1016/S1352-2310(97)00164-7, 1998.

Tang, A., Zhuang, G., Wang, Y., Yuan, H., and Sun, Y.: The chemistry of precipitation and its relation to aerosol in Beijing, Atmos. Environ., 39, 3397-3406, doi:10.1016/j.atmosenv.2005.02.001, 2005.

Tang, G. Q.: Modelling of ozone spatial-temporal distribution in the vicinity of Beijing during Olympics, Ph.D thesis, Institute of Atmospheric Physics, Chinese Academy of Sciences, Beijing, 153 pp., 2010.

Townsend, A. R., Braswell, B. H., Holland, E. A., and Penner, J. E.: Spatial and temporal patterns in terrestrial carbon storage due to deposition of fossil fuel nitrogen, Ecol. Appl., 6, 806-814, doi:10.2307/2269486, 1996.

Vitousek, P., Mooney, H., Lubchenco, J., and Melillo, J.: Human domination of Earth's ecosystems, Science, 277, 494-499, doi:10.1126/science.277.5325.494, 1997.

Wang, Y., Zhuang, G., Tang, A., Yuan, H., Sun, Y., Chen, S., and Zheng, A.: The ion chemistry and the source of $\mathrm{PM}_{2.5}$ aerosol in Beijing, Atmos. Environ., 39, 3771-3784, 
doi:10.1016/j.atmosenv.2005.03.013, 2005.

Wang, Y., Yu, W., Pan, Y., and Wu, D.: Acid neutralization of precipitation in Northern China, J. Air. Waste. Manage., 62, 204211, doi:10.1080/10473289.2011.640761, 2012.

Wesely, M. L.: Parameterization of surface resistances to gaseous dry deposition in regional-scale numerical models, Atmos. Environ., 23, 1293-1304, doi:10.1016/0004-6981(89)90153-4, 1989.

Wesely, M. L. and Hicks, B. B.: A review of the current status of knowledge on dry deposition, Atmos. Environ., 34, 2261-2282, doi:10.1016/s1352-2310(99)00467-7, 2000.

Wu, D., Wang, Y. S., Pan, Y. P., Xin, J. Y., and Tang, G. Q.: Application of passive sampler to monitor and study atmospheric trace gases in Beijing-Tianjin-Hebei area, Environ. Sci., 31, 2844 2851, 2010 (in Chinese).

Xie, Y., Xiong, Z., Xing, G., Yan, X., Shi, S., Sun, G., and Zhu, Z.: Source of nitrogen in wet deposition to a rice agroecosystem at Tai lake region, Atmos. Environ., 42, 5182-5192, doi:10.1016/j.atmosenv.2008.03.008, 2008.

Xin, J. Y., Wang, Y. S., Tang, G. Q., Wang, L. L., Sun, Y., Wang, Y. H., Hu, B., Song, T., Ji, D. S., and Wang, W. F.: Variability and reduction of atmospheric pollutants in Beijing and its surrounding area during the Beijing 2008 Olympic Games, Chinese. Sci. Bull., 55, 1937-1944, doi:10.1007/s11434-010-3216-2, 2010.

Yang, R., Hayashi, K., Zhu, B., Li, F., and Yan, X.: Atmospheric $\mathrm{NH}_{3}$ and $\mathrm{NO}_{2}$ concentration and nitrogen deposition in an agricultural catchment of Eastern China, Sci. Total. Environ., 408, 4624-4632, doi:10.1016/j.scitotenv.2010.06.006, 2010.

Yao, X., Chan, C. K., Fang, M., Cadle, S., Chan, T., Mulawa, P., He, K., and Ye, B.: The water-soluble ionic composition of $\mathrm{PM}_{2.5}$ in Shanghai and Beijing, China, Atmos. Environ., 36, 4223-4234, doi:10.1016/S1352-2310(02)00342-4, 2002.

Zhang, K., Wang, Y., Wen, T., Meslmani, Y., and Murray, F.: Properties of nitrate, sulfate and ammonium in typical polluted atmospheric aerosols $\left(\mathrm{PM}_{10}\right)$ in Beijing, Atmos. Res., 84, 67-77, doi:10.1016/j.atmosres.2006.05.004, 2007.

Zhang, L., Brook, J. R., Vet, R., Wiebe, A., Mihele, C., Shaw, M., O'Brien, J. M., and Iqbal, S.: Estimation of contributions of $\mathrm{NO}_{2}$ and PAN to total atmospheric deposition of oxidized nitrogen across Eastern Canada, Atmos. Environ., 39, 7030-7043, doi:10.1016/j.atmosenv.2005.08.023, 2005.

Zhang, L., Vet, R., O’Brien, J. M., Mihele, C., Liang, Z., and Wiebe, A.: Dry deposition of individual nitrogen species at eight Canadian rural sites, J. Geophys. Res., 114, D02301, doi:10.1029/2008JD010640, 2009.

Zhang, L., Wright, L. P., and Asman, W. A. H.: Bi-directional airsurface exchange of atmospheric ammonia-A review of measurements and a development of a big-leaf model for applications in regional-scale air-quality models, J. Geophys. Res, 115, D20310, doi:10.1029/2009JD013589, 2010.
Zhang, Q., Streets, D. G., Carmichael, G. R., He, K. B., Huo, H., Kannari, A., Klimont, Z., Park, I. S., Reddy, S., Fu, J. S., Chen, D., Duan, L., Lei, Y., Wang, L. T., and Yao, Z. L.: Asian emissions in 2006 for the NASA INTEX-B mission, Atmos. Chem. Phys., 9, 5131-5153, doi:10.5194/acp-9-5131-2009, 2009.

Zhang, X. Y., Wang, Y. Q., Niu, T., Zhang, X. C., Gong, S. L., Zhang, Y. M., and Sun, J. Y.: Atmospheric aerosol compositions in China: spatial/temporal variability, chemical signature, regional haze distribution and comparisons with global aerosols, Atmos. Chem. Phys., 12, 779-799, doi:10.5194/acp12-779-2012, 2012.

Zhang, Y., Liu, X. J., Fangmeier, A., Goulding, K. T. W., and Zhang, F. S.: Nitrogen inputs and isotopes in precipitation in the North China Plain, Atmos. Environ., 42, 1436-1448, doi:10.1016/j.atmosenv.2007.11.002, 2008a.

Zhang, Y., Wu, S. Y., Krishnan, S., Wang, K., Queen, A., Aneja, V. P., and Arya, S. P.: Modeling agricultural air quality: Current status, major challenges, and outlook, Atmos. Environ., 42, 32183237, doi:10.1016/j.atmosenv.2007.01.063, 2008b.

Zhang, Y., Liu, J., Mu, Y., Pei, S., and Lun, X.: Emissions of nitrous oxide, nitrogen oxides and ammonia from a maize field in the North China Plain, Atmos. Environ., 45, 2956-2961, doi:10.1016/j.atmosenv.2010.10.052, 2011.

Zhao, X., Yan, X., Xiong, Z., Xie, Y., Xing, G., Shi, S., and Zhu, Z.: Spatial and temporal variation of inorganic nitrogen wet deposition to the Yangtze River Delta Region, China, Water Air. Soil Poll., 203, 277-289, doi:10.1007/s11270-009-0011-2, 2009.

Zhao, Y., Wang, S., Duan, L., Lei, Y., Cao, P., and Hao, J.: Primary air pollutant emissions of coal-fired power plants in China: Current status and future prediction, Atmos. Environ., 42, 84428452, doi:10.1016/j.atmosenv.2008.08.021, 2008.

Zhao, Y., Duan, L., Xing, J., Larssen, T., Nielsen, C. P., and Hao, J.: Soil Acidification in China: Is Controlling $\mathrm{SO}_{2}$ Emissions Enough?, Environ. Sci. Technol., 43, 8021-8026, doi:10.1021/es901430n, 2009.

Zheng, X. H., Fu, C. B., Xu, X. K., Yan, X. D., Huang, Y., Han, S. H., Hu, F., and Chen, G. X.: The Asian nitrogen cycle case study, Ambio, 31, 79-87, doi:10.1579/0044-7447-31.2.79, 2002.

Zhou, J., Cui, J., Fan, J., Liang, J., and Wang, T.: Dry deposition velocity of atmospheric nitrogen in a typical red soil agroecosystem in Southeastern China, Environ. Monit. Assess, 167, 105-113, doi:10.1007/s10661-009-1034-2, 2010. 